IZA DP No. 8525

Do Cows Have Negative Returns?

The Evidence Revisited

Esther Gehrke

Michael Grimm

October 2014

Forschungsinstitut

zur Zukunft der Arbeit

Institute for the Study

of Labor 


\title{
Do Cows Have Negative Returns? The Evidence Revisited
}

\author{
Esther Gehrke \\ University of Passau \\ and German Development Institute (DIE) \\ Michael Grimm \\ University of Passau, \\ Erasmus University Rotterdam, DIW Berlin and IZA
}

Discussion Paper No. 8525
October 2014

IZA

P.O. Box 7240

53072 Bonn

Germany

Phone: +49-228-3894-0

Fax: +49-228-3894-180

E-mail: iza@iza.org

Any opinions expressed here are those of the author(s) and not those of IZA. Research published in this series may include views on policy, but the institute itself takes no institutional policy positions. The IZA research network is committed to the IZA Guiding Principles of Research Integrity.

The Institute for the Study of Labor (IZA) in Bonn is a local and virtual international research center and a place of communication between science, politics and business. IZA is an independent nonprofit organization supported by Deutsche Post Foundation. The center is associated with the University of Bonn and offers a stimulating research environment through its international network, workshops and conferences, data service, project support, research visits and doctoral program. IZA engages in (i) original and internationally competitive research in all fields of labor economics, (ii) development of policy concepts, and (iii) dissemination of research results and concepts to the interested public.

IZA Discussion Papers often represent preliminary work and are circulated to encourage discussion. Citation of such a paper should account for its provisional character. A revised version may be available directly from the author. 


\begin{abstract}
Do Cows Have Negative Returns? The Evidence Revisited

This paper addresses the apparent paradox between widespread support of cattle farming by agricultural policy interventions and negative returns to cattle as stressed in recent works. Using a representative panel dataset for Andhra Pradesh, a state in the south of India, we examine average and marginal returns to cattle. One variant of our identification strategy builds on instrumental variable estimation, where the exposure to the National Rural Employment Guarantee Act (NREGA) is used as an instrument for investment in cattle. We find average returns in the order of $-2 \%$ at the mean, but they vary across the cattle value distribution between negative 35\% (in the lowest quintile) and positive 5\% (in the highest). In contrast, marginal returns are positive over the entire distribution and, on average, as high as $13 \%$ annually. Both, average and marginal returns vary considerably not only across scale, but also across cattle breed and individual animal value. Our results suggest that cattle farming is associated with sizable non-convexities in the production technology and that substantial economies of scale as well a high upfront expenses of acquiring high productivity animals might trap poorer households in low-productivity asset levels.
\end{abstract}

JEL Classification: D24, O12, Q12

Keywords: livestock, profits, investment, India

Corresponding author:

Michael Grimm

University of Passau

Innstrasse 29

94032 Passau

Germany

E-mail: michael.grimm@uni-passau.de

\footnotetext{
* The authors would like to thank Jann Lay, Stefan Klasen, Elisabeth Sadoulet, Simon Quinn and conference participants of the Nordic Conference on Development Economics, Helsinki, the Development Economics and Policy Conference of the German Economics Association, Passau, the International Conference of the Courant Research Center Poverty, Equity, and Growth in Developing and Transition Countries', Göttingen, and the 'Poverty Reduction, Equity, and Growth Networks (PEGNet) Conference, Lusaka, for helpful comments and suggestions. The data used in this paper come from Young Lives, a 15-year study of the changing nature of childhood poverty in Ethiopia, India (Andhra Pradesh), Peru and Vietnam (www.younglives.org.uk). Young Lives is funded by UK aid from the Department for International Development (DFID), with co-funding from 2010 to 2014 by the Netherlands Ministry of Foreign Affairs, and from 2014 to 2015 by Irish Aid. The views expressed here are those of the authors. They are not necessarily those of Young Lives, the University of Oxford, DFID or other funders.
} 


\section{Introduction}

Next to the cultivation of food and cash crops, livestock farming is the most important activity of rural households in developing countries. It is widely seen as profitable activity and hence is supported by many agricultural policy interventions (see e.g. Swanepoel et al., 2010). Livestock farming or better livestock accumulation is also often seen as reliable saving device for poor households with limited access to formal banking and more generally in a context in which high inflation rates rapidly erode financial assets (Rosenzweig and Wolpin, 1993). Based on such considerations the Government in Rwanda approved in 2006 for example the 'One cow per poor family program' (Protos et al., 2011). The cow should not only supply milk, which can be an important source of nutrition and income to families, but also manure, which is a source of fertilizer for crops and biofuel for cooking. Because dairying is traditionally a female occupation, livestock farming also has an important gender dimension.

The almost 'romantic view' about the profitability of cows has recently been shaken by a paper of Anagol et al. (2013). In that paper, the authors estimate that the annual average return to owning a dairy animal in Northern rural India (Uttar Pradesh) is negative by $64 \%$ (not including the opportunity cost of capital). Even if the authors make the extreme assumption that the opportunity cost of labor is zero, they find a negative return of $6 \%$. This result is surprising given the wide ownership of cows in India and in many other places. Anagol et al. (2013) conclude that households holding ownership of cattle cannot be explained by fully rational economic behavior and put forward a number of potential alternative explanations: better quality of home produced milk, preference for illiquid savings and the social and religious value of cows. Attanasio and Augsburg (2014) have very recently revisited the issue and argue that variation in returns with weather conditions is more likely to explain why Anagol et al. (2013) find negative average returns. The authors show that Anagol et al. (2013) collected data during a drought period in which fodder was scarce and fodder prices high. They recalculate returns using three rounds of data in a different state of India (Andhra Pradesh) and find positive average returns in good years (in terms of rainfall) and negative returns in bad years.

In this paper, we also revisit the paradox. We also use data from Andhra Pradesh but from alternative years. On one hand we want to see how generalizable the findings by Anagol et al. (2013) as well as Attanasio and Augsburg (2014) are and on the other hand - and more importantly - we complement the accounting approach proposed by Anagol et al. (2013) which basically serves to calculate the average profitability of holding cows, with an analysis of the marginal profitability. Whereas average profitability just informs whether it is economically beneficial to hold a certain quantity or value of cows, estimating the marginal profitability allows deriving the benefit of an additional dollar invested in cows and shows how the profitability evolves with the value already invested. Marginal returns are thus an important parameter for households that have to decide whether to invest further in cows or rather in something else. In contrast to Anagol et al. (2013) and Attanasio and Augsburg (2014), we also address endogeneity issues that can potentially bias estimates of average and marginal returns. To this end we rely on panel data and employ an instrumental variables (IV) approach, where we instrument the value of cattle owned with the exposure to the National Rural Employment Guarantee Act (NREGA). 
The National Rural Employment Guarantee Act entitles every household living in rural areas to up to a hundred days of employment per year. The main targets of this program are the provision of basic social protection and employment to poor households as well as ensuring livelihood security in rural areas through the protection and recovery of natural resources. It was implemented between 2006 and 2008 and is currently the largest public employment program in the world and one of the most prominent anti-poverty policies in India.

The identification assumption is that access to the program relaxes liquidity constraints and possibly reduces risk and hence the need for diversification and therefore enhances the accumulation of cattle. Conversely, we assume that there is no direct link between access to the program and the returns to cow ownership.

The results of this paper are as follows. Overall, we find negative average returns to cattle, although much higher than those estimated by Anagol et al. (2013). As in their study, the magnitude of average returns crucially depends on the assumption that is made on the opportunity cost of labor. If we assume the opportunity cost of labor to be zero, the average returns vary between $11 \%$ and $23 \%$ annually. If instead we set opportunity cost of labor to roughly half the statutory minimum wage, which is the average market wage for women for unskilled labor observed in the sample, the average returns are in the order of $-2 \%$ on average and vary between negative $35 \%$ (in the lowest quintile of cattle value) and positive 5\% (in the highest). Similarly to Attanasio and Augsburg (2014) we find that average returns are considerably higher in times of favorable weather conditions (positive $8 \%$ on average in 2009/10) than in periods with low rainfall levels (negative $14 \%$ on average in 2007). In contrast to average returns, marginal returns are positive at all levels of cattle value even after accounting for labor costs. Our non-experimental results suggest that annual marginal returns are $13 \%$ on average. Instrumental variable estimation suggests that marginal returns are considerably higher and in the order of $40 \%$ to $65 \%$ annually.

In contrast to estimates from the off-farm sector (see e.g. Banerjee and Duflo, 2004; McKenzie and Woodruff, 2006; De Mel et al., 2008; Kremer et al., 2010; Grimm et al., 2011; Fafchamps et al., 2014; Dodlova et al., 2014), our results suggest that livestock farming is characterized by a non-convex production technology, due to substantial economies of scale and due to differences in animal prices and productivity across breeds. This results in a negative profitability of cattle farming at low value of cattle and close to zero marginal returns up to above average cattle values. Because the profitability is positive only for larger values of cattle, many households seem to be trapped with little livestock and low returns.

We discuss the robustness of our findings and all underlying assumptions as well as what is reasonable to assume in terms of the opportunity cost of labor. Overall we believe that the findings give little reason to speak of a paradox of cattle accumulation. More generally, we think the findings and discussion make a useful contribution to an important debate initiated by Anagol et al. (2013), Morduch et al. (2013), Attanasio and Augsburg (2014) and others. ${ }^{1}$

\footnotetext{
${ }^{1}$ As Anagol et al. (2013), Morduch et al. (2013) also conclude with negative returns. The authors provide evidence that women in rural Andhra Pradesh when given the choice between working at minimum wages and between dairy production seem to favor labor market employment over dairy production suggesting that the return from wage work at least exceeds the minimum wage.
} 
The remainder of this paper proceeds as follows. Section 2 provides some background information on livestock production in India and presents the data used in the analysis. Section 3 discusses the challenges in estimating returns to cattle and presents the estimation strategy. Section 4 proceeds with results, while section 5 puts forward potential explanations for observed heterogeneity in returns. Section 6 concludes.

\section{Data and context}

India is the second largest cow milk producer in the world. ${ }^{2}$ Cows play an important role in the lives and livelihoods of rural households in India. They are considered sacred in the Hindu religion and cattle slaughter is prohibited in most states of India. At the same time, dairy products are widely consumed in India as they are the main source of animal proteins of many households.

The data used in this paper are the Young Lives Survey (YLS) data for Andhra Pradesh. Andhra Pradesh is the third largest milk producer in the country, only Uttar Pradesh and Rajasthan have a higher milk production per year. ${ }^{3}$ The slaughter of cows and calves is prohibited since 1977, and bulls and bullocks can only be slaughtered upon permission, e.g. if owners can prove that these can neither be used for reproductive purposes nor in agricultural production. ${ }^{4}$

Young Lives is a long-term research project that seeks to understand the changing patterns and long term consequences of childhood poverty. For that, it collects panel data in Ethiopia, India (Andhra Pradesh), Peru and Vietnam. The data is intended to cover a time span of 15 years upon completion of the project. The dataset on Andhra Pradesh consists of 3019 households living in six different districts. The selection of districts under the YLS ensured that all three geographical regions were represented in the survey as well as poor and nonpoor districts of each region. Classification of districts was done along economic, human development and infrastructure indicators (Galab et al., 2011). This sample design ensures that the YLS is broadly representative for the population of Andhra Pradesh.

Three rounds of interviews were conducted so far, in 2002, 2007 and 2009/10. ${ }^{5}$ Panel attrition is relatively low: in 2009/10, 2910 households could be revisited, which gives an attrition rate of $3.6 \%$ (Galab et al. 2011). For reasons of comparability, only the second (2007) and third (2009/10) round are considered in the current analysis.

\footnotetext{
${ }^{2}$ The FAO estimates the total production of cow milk to be around 54 Million Metric Tons in 2012. If buffalo milk and cow milk are considered jointly, India is the largest producer in the world with 110 Mio. Metric Tons produced in 2012. The largest cow milk producer worldwide is the US with about 91 Mio. Metric Tons of fresh milk produced in the same year. Source: FAOSTAT

${ }^{3}$ Department of Animal Husbandry, Dairying and Fisheries, Ministry of Agriculture.

${ }^{4}$ This implies, that the value of a cow will be zero once it is no longer in reproductive age, since it cannot be sold for slaughter. Of course, reports exist throughout the country of unproductive animals being sold off to other states in which cattle slaughter is not prohibited. But in this paper we assume that the market value of a cow approaches zero with end of fertility.

${ }^{5} \mathrm{~A}$ fourth round of data was collected in 2013 , but these have not yet been made publicly available.
} 
Although the main focus of the survey lies on child development, it also collects information on households' characteristics, their income sources, ownership of assets and production strategies. In particular the YLS contains a section about livestock which inquires about the type, number and current value of different animals, about households' expenses for fodder, veterinary services and other expenses. Households are also asked to report on the income they generated in the past 12 months from the sale of milk and dairy products and on the costs incurred for producing this output.

Because we are interested in the productivity of cattle, we restrict the sample to households living in rural areas. Although it is still common to see cattle being held in Indian cities, the profitability of farming cattle and producing dairy is likely to be very different in cities as opposed to rural areas. Furthermore, the sample is restricted to households that lived in the same locality in 2007 and 2009/10 because we assume that livestock is one of the fist things to be sold when a household decides to move. This results in a final sample of 2080 households (4160 observations). Out of these, 678 households own cattle (either cows or buffaloes) in either one or both of the survey rounds. The sample of cattle owners contains 975 observations (463 obs. in 2007 and 512 in 2009/10). ${ }^{6}$ Finally, we exclude influential outliers from our analysis as discussed in Section 4. This eliminates three observations reducing the sample to 972 observations.

Summary statistics of general household and farming characteristics are presented in Table 1. We split the sample by cattle ownership and by year. As we can see, cattle owners are significantly different from non-cattle owners. In particular, cattle owning households are more likely to be headed by males and have older household heads. Households who own cattle are also larger on average. In 2007, cattle owning households have 6.2 members as compared to 5.3 members in households without cattle. Both groups are not statistically different in the proportion of literate household heads, which is very low (around 30\%) in both groups. Households with cattle are also significantly wealthier than non-cattle owners: Households with cattle have on average more land, which is the primary indicator for wealth in rural India. But cattle-owners have also better quality houses (in terms of the structure of roof, walls and floor), more consumer goods (such as television, radio, refrigerator etc.) and are more likely to have access to electricity, water and sanitation. ${ }^{7}$ The difference in wealth is more pronounced in 2007 than in 2009/10, although it is statistically significant in both periods. The income structure is also very different between both groups. Although both have similar income from non-agricultural activities (equality of means cannot be rejected), cattle owners have a much higher income from crop production than the rest of the sample.

Table 2 presents some household level information about income and cost associated with cattle farming and dairy production. As we can see, the total value of owned cattle increased between 2007 and 2009/10 from INR 12,150 to INR 13,600 (or US\$ 262 to US\$293, in constant July 2006 values). ${ }^{8}$ This

\footnotetext{
${ }^{6}$ A total of 26 observations were excluded from the sample of cattle owners, because households owned cattle as well goats or sheep. Since we cannot distinguish between dairy income from cattle and dairy income from goats or sheep in the dataset, we decided to drop these observations from our analysis.

${ }^{7}$ This information is summarized in three indices: housing quality index, consumer durables asset and housing services index. The wealth index reports the simple average of these three indices.

${ }^{8}$ This is the total reported end of period value of all grown female cows and buffaloes owned
} 
increase is partly reflected in a slight increase in the quantity of cattle owned and partly in the increase of the average value of the cows and buffaloes owned by these households. The composition of animals owned also changes between 2007 and 2009/10: we find a considerable increase in the number of cows in the sample, the average number of modern variety cows, thus European breeds and their cross-breeds, owned by each household increased from 0.17 to 0.26 and the number of traditional cows increases from 0.78 to 0.83 . In contrast, the number of buffaloes seems to have decreased over time, for both modern and traditional varieties. The number of calves per cow or buffalo is 0.48 in 2007 and 0.69 in $2009 / 10$, which gives an average annual reproduction rate of about $58.9 \%$. The value of calves over both rounds corresponds to about $17.4 \%$ of the total value of adult female cattle. ${ }^{9}$

Households owning cattle can generate income from mainly two sources: the sale of milk and other dairy products and the sale of calves. ${ }^{10}$ Calving is the precondition for milking and hence for generating income from the sale of dairy products. ${ }^{11}$ Calves can either be sold shortly after birth, be raised and sold later or be kept by the household for future dairy production. ${ }^{12}$ In the survey, households were asked to report the total income from the sale of milk and dairy products in the past 12 months (including the value of their own consumption). ${ }^{13}$ As we can see in Table 2 the annual income from the sale of dairy products increased between 2007 and 2009/10 from INR 3,600 to INR 6,200 (US\$ 77 to US\$133). The variation in this variable is considerable, the standard deviation is more than twice the sample mean in both years.

Inputs to dairy production are mainly fodder, but also veterinary costs, insemination costs and labor. The cost variables are obtained from two sections. In the livestock section, households were asked to report their total expenditures on fodder, veterinary services and other expenses incurred for all animals owned in the last 12 months. In order to derive from this information the expenditure incurred for cattle, we divide these variables by the total value of all animals owned by the household. We then multiply it by the reported value of cattle (mother cows, mother buffaloes and calves) in the household. Expenditure on fodder make up for almost $90 \%$ of total paid-out cost. In 2007 spending on

by the household. Two households reported the value of their animal to be zero. In order not to lose any information, we replaced the value of these cows by the 5 th percentile of cattle value observed in the sample (INR 437). We use July 2006 official exchange rates to convert INR to US\$.

${ }^{9}$ Again, a few households reported the value of their calves to be zero, and it is not clear from the data whether this information was simply not known or misreported. Therefore, we replaced the value by the 5 th percentile observed in the sample: INR 95.

${ }^{10}$ Households can also sell dung, which is used for manure as well as a cooking fuel in rural India. Anagol et al. (2013) include this income source in their estimation, but since the survey used in this paper does not collect any information about dung, we cannot account for it. In Anagol et al. (2013), income from sale of dung makes up for 14-15\% of total revenue, which suggests that we might be underestimating the 'true' returns considerably.

${ }^{11}$ For more information about lactation cycles, etc. see Anagol et al. (2013).

${ }^{12}$ The value of calves reported by the household reflects current ownership and hence excludes all calves that were sold before the survey took place. Income from sale of calves was not included explicitly in the survey, which implies that we probably underestimate the reproduction value of cattle.

${ }^{13}$ We cannot assess with the data used in this paper in how far households correctly account for the value of their own milk consumption. It is likely that we have non-random measurement error in this variable because households who operate at a lower scale presumably consume a higher share of produced milk within the household. 
fodder was INR 1,800 (US\$ 39) on average, whereas households spent only INR 200 (US\$ 4) on veterinary services and INR 30 (US\$ 1 ) on other items. ${ }^{14}$ Another source of information about the costs associated with cattle farming is the income section. There, households were asked about the total costs associated with producing and selling dairy products in the last 12 months. Households are asked to also include expenditures on fodder and veterinary services for those animals that produce dairy. ${ }^{15}$ This information is captured by the variable 'Total cost from sale of dairy products'. Cost estimates from both sections are somewhat different, which is why we estimate returns based on both cost estimates for additional robustness.

In order to account for labor allocated to caring for the animals and for dairy production, we construct a time variable based on the 2007 survey information. In the 2007 survey, all household members (incl. children) are asked about their three most important activities and about the number of hours per day, days per week and weeks per month they spend on this activity. Form this question, we compute an aggregate variable which captures the total hours per year households spend on livestock farming. To obtain the hours worked in cattle farming, we divide this value by the number of adult equivalent animals owned by the household and multiply it by the number of cattle (both calves and adult cows/ female buffaloes). ${ }^{16}$ This gives an estimate of total hours per year households spend on caring for their cows, female buffaloes and calves. Because the 2009/10 questionnaire did not include the same information we have to impute this data. In order to do so, we use the 2007 data and run a simple OLS regression of the number of hours spend on cattle per year on the number of currently owned cattle. Because we observe that the number of hours households spend on their animals increases with the number of owned animals, but at a decreasing rate (due to complementarities), we also include the square of this variable. ${ }^{17}$ From this regression, we can predict for each observation the hours per year spent on cattle farming and dairy production. This predicted time variable for 2007 and 2009/10 is reported in Table 2 .

Finally, Table 2 summarizes the occurrence of shocks in the sample. Two variables are of interest. The variable 'Shocks affected livestock' is a dummy indicating the occurrence of any shock in the past four years that affected a household's livestock. The share of households reporting any of such shocks increases slightly from $13 \%$ in 2007 to $19 \%$ in 2009/10. In contrast, rainfall was much lower in the period of reference of the 2007 interviews. The deviation from the long-term average annual rainfall at sub-district level is negative by $26 \%$ in 2007, as compared to a zero deviation from the long-term average in 2009/10.

\footnotetext{
${ }^{14}$ Total expenditure on cattle is the sum of these three variables. Expenditure on fodder was only multiplied by the value of adult female cattle, hence we assume fodder expenses for calves to be zero.

${ }^{15}$ According to personal communication of the survey team, the variable also includes wage cost of the household for caring for the animals and marketing the product, but when comparing this variable with the costs variable computed from the livestock section, it does not seem to be much higher, which it would have to be if labor costs were adequately accounted for.

${ }^{16}$ The adult equivalent of cattle is 0 for poultry and birds, 0.2 for sheep, goats and pigs, and 1 for bullocks, bulls, cows, buffaloes and calves. We assume it equals 1 for calves in order to account for increased labor input when cattle is being milked.

${ }^{17}$ The coefficient of the square of that variable is statistically significant at the $1 \%$ level (p-value 0.002).
} 


\section{Estimation strategy}

In order to understand how profits to cattle farming develop with cattle value, breed and input allocation, we estimate both average and marginal returns to cattle. As described above, the main outputs from cattle farming are milk and dairy products as well as calves. The sales revenue of these outputs can be summarized by $p Q$, where $p$ is the price of both outputs. Paid-out costs associated with cattle farming are mainly expenditures on fodder, veterinary services and insemination. We assume opportunity cost of capital to be zero as a starting point.

Dairy production is a very labor intensive occupation, hence we must account for opportunity costs of time properly. Using estimates provided by Anagol et al. (2013) we value the total time a household allocates to cattle at a hourly wage of INR 5 (US\$ 0.10). Daily female wages for unskilled work vary between INR 45 and INR 50 in our sample in 2006, and since caring for livestock is mostly in the responsibility of women and children it seems reasonable to assume opportunity costs of labor of INR 5 per hour. This is about half the statutory minimum wage and the wage paid under NREGA, which was INR 80 (US\$2) in the financial year 2006/07 and INR 100 in the FY 2009/10. ${ }^{18}$ In constant July 2006 values, the NREGA wage of $2009 / 10$ is INR 79 , thus real wages in the public works program seem not to have increased between both survey rounds. ${ }^{19}$ In contrast, market wages seem to have increased from 2006 to 2009 in real terms. By 2009, market wages for unskilled female labor are roughly INR 80 per day (in 2006 prices). As of now we do not correct for this increase in wage levels between 2006 and 2009, because we do not expect that women and children would have the option to get full employment at these wage levels.

Cattle depreciates strongly over time, because cows produce milk only as long they are fertile. The depreciation rate cannot be estimated with the data used in this paper, because it does not contain any information about livestock age. We thus have to rely on secondary sources for this value. Data from the Animal Husbandry Department of the Government of Andhra Pradesh suggest that a fertile cross-breed cow costs about INR 10,530 (US\$227) in Andhra Pradesh in the financial year 2008/09 (AHD-GAP, 2009). ${ }^{20}$ Cows enter reproductive age at about 2.5 years (buffaloes after 3 years) and are expected to calve about 5 times during their lifetime (Ruvuna et al., 1984). ${ }^{21}$ Given an average reproduction rate of around 0.59 per year (as observed in the sample), we can assume cows and buffaloes to be productive for about 8.5 years after entering reproductive age. Cows would thus be fertile up to the age of about 11 years, buffaloes up to the age of $12 .{ }^{22}$ As explained earlier, we expect the real value of a cow or buffalo to be zero once it reaches that age. Assuming linear depreciation

\footnotetext{
${ }^{18}$ This is equivalent to $\$ 7$ (PPP conversion factor, private consumption).

${ }^{19}$ The NREGA wage is always set at the state minimum wage and in many cases exceed wages that are paid for casual labor in agriculture. Due to the huge size of the program, this is about the first time that the minimum wage has become binding in India.

${ }^{20}$ In July 2006 prices. The average price of a Graded Murrah buffalo was roughly the same. These prices vary between districts however.

${ }^{21}$ Of course these are rough averages, reproduction rates, and number of calves per animal vary across breeds. Cross-breeds seem to have higher reproduction rates than traditional varieties (Mukasa-Mugerwa, 1989).

${ }^{22}$ Some studies even refer to twelve years of productive life for cross-breed cows (Ghule et al., 2012).
} 
of cattle, this would imply that each animal depreciates by around INR 1,240 (US\$ 27) per year. If we assume that the depreciation is non-linear, an annual relative decrease in cattle value of $20 \%$ would imply that animals have an end of fertility value of INR 1,400 (US\$ 30), which is slightly more than 1/10 of the initial value. This depreciation rate is also used by government entities in their project reports (AHD-GovHP, 2014) and is more conservative than a linear depreciation. $^{23}$

A profit function (net of depreciation) can thus be written as follows:

$$
\pi_{t}=p Q_{t}-c K_{t}-w L_{t}-\delta K_{t}
$$

$Q_{t}=f\left(K_{t}, L_{t}\right)$ is the production of milk and calves, with capital (current value of cattle) and labor as inputs. Opportunity costs of labor are captured by $w L_{t}$ and $c K_{t}$ captures all other costs associated with cattle farming (e.g. fodder, veterinary services, etc.). ${ }^{24}$ We start by assuming that fodder input does not enter the production function directly because we expect the current value of a cow or buffalo to reflect the general health (and also nutritional) status of the animal. We include fodder into the production function as a robustness check and find that our main results do not change much. The depreciation $\delta K_{t}$ is the change in value of cattle from the current period $t$ to the next period $t+1$, or simply $K_{t}-K_{t+1}$. The production function $f\left(K_{t}, L_{t}\right)$ can be linear or constant elasticity of substitution (CES) type. Average and marginal returns to cattle would then be:

$$
\frac{\pi_{t}}{K_{t}}=p \frac{Q_{t}}{K_{t}}-c-\frac{w L_{t}}{K_{t}}-\delta
$$

and

$$
\frac{\partial \pi_{t}}{\partial K_{t}}=p \frac{\partial Q_{t}}{\partial K_{t}}-c-\delta
$$

In contrast to average returns, our estimates of marginal returns strongly depend on assumptions concerning the functional form of the production function. In order to get a better idea of the pattern of marginal returns to cattle, we try both parametric and semi-parametric approaches.

We start with a linear production function, where estimating marginal returns is straightforward. We estimate profits (net of depreciation) as a function of cattle value and account for time-constant unobservable heterogeneity $u_{i}$ and period effects $\gamma_{t}$. We estimate:

$$
\pi_{i, t}=\beta_{0}+\beta_{1} K_{i, t}+u_{i}+\gamma_{t}+\epsilon_{i, t}
$$

Alternatively, we also include the square of cattle value, which allows marginal returns to increase or decrease with cattle value. In a CES type production function, such as $f\left(K_{t}, L_{t}\right)=K_{t}^{\alpha} L_{t}^{\eta}$, the functional form imposes decreasing marginal returns. These would be $\partial \pi_{t} / \partial K_{t}=\alpha p Q_{t} / K_{t}-c-\delta$. Calculating marginal returns under CES functional form assumptions, requires an estimate

\footnotetext{
${ }^{23} \mathrm{~A}$ relative depreciation seems more appropriate here because we do not know the initial value but only the current value of each animal. We would otherwise introduce the rather unrealistic assumption of equal initial value across breeds and animals.

${ }^{24}$ We ignore land as an input here, because cattle is mostly kept close to the house and not on fields in India.
} 
of $\alpha$, from which the depreciation rate and marginal costs will have to be subtracted. To obtain $\alpha$, we estimate the log-transformation of the production function (again also including household fixed and period effects):

$$
\log \left(p Q_{i, t}\right)=\beta_{0}+\alpha \log \left(K_{i, t}\right)+\eta \log \left(L_{i, t}\right)+u_{i}+\gamma_{t}+\epsilon_{i, t}
$$

And finally, we leave the functional form unrestricted and estimate marginal returns in a semi-parametric framework. In order to do so, we first smooth the explanatory variable of interest using restricted cubic splines. This procedure creates variables containing a restricted cubic spline of cattle value. Together these add up to a continuous smooth function that is linear before the first and after the last knot and piecewise cubic polynomial between the knots. Then, after controlling for observable household characteristics, inputs and shocks, we estimate profits using the smoothed cattle value variables. A restricted cubic splines approach seems especially interesting in our framework, because it allows estimating the relationship between profits and cattle value as a piecewise non-linear function (Royston and Sauerbrei, 2007). Because it is nonetheless continuous, it has the additional advantage that the first derivative of the expected outcome with respect to cattle value can be obtained analytically at each point and doesn't have to be approximated numerically. ${ }^{25}$ We restrict the number of knots to five and follow Harrell's (2001) recommendations to place the knots at equally spaced percentiles.

Estimating returns with observational data is challenging for a variety of reasons. First, we have good reasons to assume that unobservable household characteristics $u_{i}$ are correlated with both, the observed value of cattle and profits. Estimating returns in a fixed effect model can partly remedy this problem by accounting at least for time-constant unobservable characteristics. The only draw-backs associated with the fixed effects model are that the panel is rather short and therefore offers only limited possibilities to use within household variation to estimate the parameters of interest and that the panel is not fully balanced because many households seem to have changed their production strategies by moving in or out of cattle farming and by increasing their herds with other livestock such as sheep or goats. ${ }^{26}$ Second, capital stocks are usually measured with high imprecision and the current value of a farmer's cattle is probably no exception. This could lead to attenuation bias, where marginal effects would be biased towards zero due to measurement error in the explanatory variable. Third, reverse causality i.e. the fact that in the presence of capital market imperfections, higher profits lead to faster capital accumulation might cause an upward bias in estimated returns.

We try to address these sources of bias by employing an instrumental variables approach, where the exposure of households to the National Rural Employment Guarantee Act (NREGA) is used as an instrument for changes in cattle value. The NREGA could affect cattle accumulation due to different reasons, the most prominent of them being increases in available income which raises the possibilities of households to invest their income in productive assets. Also, we could expect the better risk management opportunities to encourage

\footnotetext{
${ }^{25}$ This has the advantage of more stability in the estimates and the possibility to compute standard errors without having to rely on bootstrap procedures.

${ }^{26}$ Remember that we have to exclude all households with other milk producing animals because the questionnaire does not distinguish between these different sources of milk production.
} 
households to reallocate their savings to more productive and possibly less liquid investment goods. Lastly the NREGA could also have a negative effect on cattle accumulation because opportunity costs of labor increase, due to better employment opportunities for women (Morduch et al., 2013). Table 9 shows that the NREGA is indeed positively associated with the stock of cattle: households with access to the NREGA invest between INR 5,700 (US\$122) and INR 7,300 (US\$ 158) more in their cattle stock.

For the NREGA to be a valid instrument for cattle value, we must be sure that it is independent of potential outcomes, hence strictly exogenous, and that it affects the ownership of cattle alone and not the productivity of cattle directly or indirectly through other factors that determine the productivity of cattle. ${ }^{27}$ We use two different variables as instruments. First, we use an indicator variable that takes the value one two years after households get access to the NREGA at district level. Secondly, we explore the variation of treatment intensity of the NREGA and use the spending under the NREGA (lagged by 2 years) at the sub-district (e.g. block) level as instrument. ${ }^{28}$ We are relatively confident that these two instruments fulfill the exogeneity restrictions. The decision, which districts should introduce the National Rural Employment Guarantee Scheme first, was taken a few years before the implementation started. The scheme should have been introduced in the poorest districts of India first. But in our sample, the districts introducing the NREGA in the first phase are not very different from the remaining districts in term of general economic characteristics. ${ }^{29}$ Interestingly, milk production levels are much lower in the districts that introduced NREGA first, as compared to the remaining two sample districts (AHD-GAP, 2009). This could be a sign for differences in the profitability of farming cattle across districts. But, if any, this would rather downward bias our estimates. The treatment intensity at the sub-district level should also be exogenous to potential outcomes. Treatment intensity could be endogenous if funds allocated to blocks responded to rainfall shocks and if these rainfall shocks also affected the productivity of cattle, which is likely to be the case due to the reduced availability of green fodder in periods of drought. However, the amount of funds to be sanctioned per block is defined between December and March for the following financial year (April to March). ${ }^{30}$ Because we are using

\footnotetext{
${ }^{27}$ What we cannot assess with the data used here, is the extent to which the NREGA affects households' time allocation to different tasks and therewith the amount of labor allocated to cattle farming. However, since we use imputed data on time allocation (based on 2007 information), we treat labor allocation and the opportunity cost of labor as constant over time and across regions. With that we hope to isolate the effect of the NREGA on returns to cattle through the investment channel.

${ }^{28}$ We introduce a two year lag because we want to make sure that the instrument used does not overlap with the reporting period. Interviews were held over a period of several months and administrative data are only available financial year-wise.

${ }^{29}$ The implementation of the NREGA was intended prioritize India's 200 poorest districts, subsequently extending to the remaining districts. India has a total of 655 districts, of which 625 had introduced the NREGA as of 2008. The 30 remaining districts were urban districts. In 2003 the Planning Commission of India elaborated clear rules stating which districts should be included in which round of implementation of the NREGA. However, the process of district selection was marked by tough political negotiations due to the huge size and financial relevance of this program, which saw the rules not strictly followed. The result is that we find both wealthier and poorer districts among all three groups.

${ }^{30}$ The amount sanctioned depends on a village's list of projects, which has to be approved by the block program officer. The block program officer has to estimate employment demand for the following financial year and consolidate all village lists before submitting the Block
} 
spending levels that are lagged by two years and we additionally control for rainfall shocks, we are relatively confident that the instrument is uncorrelated with potential realizations of current returns.

IV estimates are unbiased estimates of average marginal returns if marginal returns are homogeneous in the population. If however, marginal returns are heterogeneous and investments in cattle induced by the NREGA vary across population subgroups, then the IV estimation will provide a local average treatment effect (LATE) instead. LATE is a weighted average of marginal returns to cattle, with the heterogeneous returns weighted by the amount of investment the NREGA caused in each of these groups (Angrist and Pischke, 2009). In our case the LATE can be very different form the average marginal return because those households with higher marginal returns to cattle will also be more likely to invest any additional income generated through the NREGA to increase their herd size. This would imply that the IV estimate is likely an upper bound of the true marginal effect.

We follow the approach of de Mel et al. (2008) in order to understand how different the LATE is from the average marginal return. To do so, we test whether household characteristics that could be potentially correlated with returns to capital also determine their investment decisions. We find evidence that larger households, as well as households with lower education are more likely to invest in cattle when having access to the NREGA. We also find that households with higher asset wealth invest more, while land ownership seems not to influence the investment decision (results not reported here).

\section{Returns to cattle}

\subsection{Average returns}

Following Anagol et al. (2013) we start by calculating average returns to cattle. We calculate profits (net of depreciation) for each household and divide it by $K_{t}$, e.g. the cattle value at the beginning of the period. The results that draw on the costs reported in the income section of the survey are reported in Table 3. These are our preferred estimates. However, to check robustness, we present in Table 4 also the results that draw on the costs reported in the livestock section (see also Section 2). Both estimates provide fairly similar results: average rates of return are negative at the mean of cattle value (INR 12,920 or US\$279) by roughly $2 \%$ annually. ${ }^{31}$ Furthermore, we find that average returns are lower at lower quintiles of investment in cattle. They range from $-35 \%$ annually (in the lowest quintile) to positive $5 \%$ annually (in the highest). Only those households with animals worth at least INR 18,900 (US\$ 408) are able to generate positive average returns. And even in this range, returns average at only about 5\% annually, which is well below the estimates of returns to capital in micro and small non-agricultural enterprises in India (see e.g. Banerjee and Duflo, 2004).

\footnotetext{
Employment Guarantee Plan to the district program coordinator. The district council (zilla parishad) has to approve all plans before transferring them to the state government.

${ }^{31}$ Theoretically, we would expect that the current value of a cow reflects the discounted future returns of the cow. Which seems to be the case here: current value of cattle is about five times as much as annual profits from cattle farming. Hence assuming that the average animal in the sample has four to five more years of productive life (or 8-10 years in total), the current value reflects roughly the sum of future profits.
} 
One of the drawbacks to the accounting approach is that it is difficult to understand the circumstances under which observed profits come about. By calculating averages, we completely ignore external factors that might be driving observed results. Attanasio and Augsburg (2014) stress the importance of adequately accounting for the effects of shocks on the productivity of animals. Below average rainfall for example will likely affect the productivity of cattle because fodder is less accessible and this will affect both the weight of animals as well as their milk production. When we split the sample by time periods (Table 3 ), we find positive average returns at the mean in 2009/10 (8\%) as opposed to negative returns in $2007(-14 \%)$. This is likely due to the fact that most households had faced severe rainfall shortages during the period of reference of the 2007 interviews, whereas rainfall levels were close to the long-term average in the 2009/10 reference period.

Still the general pattern of increasing average returns with cattle value persists even after splitting the sample by time periods. If we look at differences in animal productivity and costs per animal across quintiles, we find some indications why returns vary so much with cattle value. First of all, income per animal increases continuously with cattle value: it averages at around INR 2,000 (US\$ 43 ) in the lowest quintile and more than doubles in the fifth quintile (INR 4,200 or US\$ 91). ${ }^{32}$ This plausibly suggests that the animals' productivity is reflected in reported current values. At the same time, costs per animal are higher in the lowest two quintiles (INR 2,400 or US\$ 52) than in the third (INR 2,100 or US\$ 45) and fourth quintiles (INR 1,900 or US\$ 41). Only in the fifth quintile do total costs increase again to INR 2,100 (US\$ 45) per animal. Higher costs per animal at lower cattle value combined with low productivity of these animals can thus partly explain the observed pattern in average returns.

Obviously in these calculations, our assumptions regarding the opportunity costs of labor are crucial. If we set for instance the opportunity costs of labor to zero, average returns are positive throughout all quintiles and highest at the lower quintiles. We started with the assumption of equal opportunity costs of time across households and we observed that the average time allocated to each animal decreases with the number of animals owned. This implies higher labor costs per animal for households operating at a smaller scale. But if labor costs are in contrary lower than average in the lower quintiles, for example because complementarities with other household activities can be better explored with few animals, then this would likely change our results.

To further understand the investment behavior of cattle farmers and to see whether additional investment in cattle is or is not beneficial, we now study marginal returns to cattle and then look in more detail into the cost structure.

\subsection{Marginal returns}

We rely now on a parametric approach and consider three types of production functions: linear, quadratic and CES. All three functional forms seem to fit the data fairly well. ${ }^{33}$ Later we also estimate marginal returns semi-parametrically

\footnotetext{
${ }^{32}$ Income is calculated as the sum of income from sale of dairy products and the current value of calves.

${ }^{33}$ We regress income from cattle farming on the value of cattle and correlate predicted income with actual income to get an impression of how well each functional form fits the data. The square of the correlation coefficient then gives the R-square. The quadratic production
} 
leaving the functional form of the production function unspecified. As mentioned earlier, we drop three observations based on the DFITS statistic and cutoff values recommended by Belsley et al. (1980) in order to reduce the influence of outliers. ${ }^{34}$

The estimates of marginal returns assuming a linear or quadratic production function are reported in Table 5. Shocks and socio-economic characteristics are included as controls in all estimations. Five different specifications are presented. Column 1 reports OLS estimates for 2007. Actual labor instead of imputed labor is included to test for returns to labor. We allow returns to labor to vary with labor input by including the square of the time variable as well. $^{35}$ As we can see, returns to labor seem to be convex, being very high and negative at average levels of time allocation and only becoming positive with time allocation above the 95th percentile. From the 2007 sample, it also seems that marginal returns to cattle are zero. However, as mentioned earlier, this might be simply due to the fact that 2007 was a drought year and fodder only scarcely available. If we re-estimate column (1) without labor inputs the estimated return on cattle is very close to the one where labor inputs are controlled (point estimate of -0.02), hence we are confident that our estimates on the pooled sample are not biased by the omission of labor. Column 2 reports pooled OLS estimates for the full sample. The point estimate of cattle value is 0.13 , suggesting marginal returns to cattle of about $13 \%$ annually. In column 3 , we add the square of cattle value to explore potential non-linearities in returns. The coefficient of the squared term is close to zero and not statistically significant, which suggests that marginal returns seem to be fairly constant across the distribution of cattle value. When accounting for unobserved heterogeneity in random effects models (column 4), the estimates of marginal returns remain exactly the same. In the fixed effect model, however, estimates drop in size considerably (column 5). The most probable reason for this strong reduction in coefficient size is the fact that the panel is relatively short and unbalanced, quite some households own cattle only in one of the two survey periods.

Alternatively, we estimate marginal returns to cattle assuming a CES functional form. For that, we start by estimating Equation (5) to get an estimate of $\alpha$. Results are reported in Table 6. Again, the first column shows OLS estimates for the year 2007 to see whether the omission of labor inputs in the pooled sample matters. Again, returns to labor are found to be negative. ${ }^{36}$ As above, if we omit the labor input from the estimation the coefficient associated with cattle value is almost unchanged (point estimate of 1.1, not reported in

\footnotetext{
function seems to fit the data best with an R-square of 0.42 . However, there is not much difference in the R-squares of all three regressions: the R-square using a CES function is 0.40 and is 0.39 using a linear functional form.

${ }^{34}$ We calculate the DFITS statistic in our estimation of marginal returns assuming a quadratic production function. We choose the quadratic production function for this procedure instead of the linear, because it leads us to drop three observations as compared to two observations in a linear production function framework. Furthermore, two of the three observations would have to be dropped in the linear function as well. The recommended cutoff value is $2 / \operatorname{sqrt}(\mathrm{k} / \mathrm{N})$ with $\mathrm{k}$ being the degrees of freedom plus one and $\mathrm{N}$ the number of observations.

${ }^{35}$ Labor input is observed only in 2007 and can be included as a control only in that year. Hence in the estimates based on the pooled sample (cols. (2) to (5)) labor inputs are omitted. Recall, above we had used imputed labor inputs to calculate profits and average returns.

${ }^{36}$ The point estimate of log labor is positive but very small, if we compute marginal returns using the same formula as for returns to cattle, we find negative returns in the order of $300 \%$.
} 
table). The second column presents results of pooled OLS estimation without labor. The third and the fourth column present results of random effects and of fixed effects estimations, respectively. Table 6 shows that the estimates for $\alpha$ are large and statistically significant for most specifications. The size of the coefficient is similar throughout specifications (1) to (3), ranging between 0.94 and 0.99. The coefficient of cattle value is again lowest in the fixed effects model.

We calculate marginal returns to cattle at two different values of $\alpha$ (e.g. the coefficients of the cattle variable) and for all quintiles as well as at the mean of cattle value (INR 12,900 or US\$279), income (INR 6,500 or US\$141) and cost (INR 1,800 or US\$40). Results are reported in Table 7. As we can see, estimated marginal returns are positive for all $\alpha$. At the highest value of $\alpha$ (0.99), marginal returns at the mean are $16 \%$ annually. At the lower estimate of $\alpha(0.94)$, estimated marginal returns at the mean are $13 \%$. This is about the same as the return calculated in levels (cf. Table 5). At the third quintile of cattle value (INR 8,900 or US\$193), income and cost values, the marginal return to cattle is slightly lower at $10-13 \%$ per year, but again, fairly close to linear estimates. For all $\alpha$, marginal returns are highest at the lowest and at the highest quintiles of cattle value. This contradicts the notion of decreasing marginal returns inherent to CES production functions. The reason for this pattern is the fact that we are multiplying $\alpha$ with different combinations of observed output and cattle value instead of keeping all other inputs (e.g. labor) constant.

As mentioned before imposing a particular functional form might not be appropriate if the functional form is a priori unknown. We therefore proceed with estimating marginal returns semi-parametrically, as discussed in Section 3. Results are shown in Figure 1. Interestingly, marginal returns seem to follow a U-shape, being quite high at very low levels of cattle value and falling with increasing cattle value. The minimum seems to lie at cattle values of around INR 15,000 (US\$ 323). At higher levels, marginal returns increase again, reaching their maximum at cattle values of roughly INR 35,000 (US\$ 755). After that they seem to remain constant at about $18 \%$ per annum. Because confidence intervals at low levels of cattle value are very large, we cannot reject the possibility of constant marginal returns at low levels of cattle value. However, confidence bands are much narrower on the increasing part of marginal returns, so that we can be quite confident that returns increase to some extend with cattle value before becoming constant again. ${ }^{37}$

To see whether we can find this U-shape also in a parametric estimation, we estimate marginal returns separately for each quintile of cattle value. We use again a linear production function. As shown in Table 8, marginal returns are indeed highest in the lowest two quintiles, drop in size in the 3rd and 4th quintile and recover again in the 5th quintile. However, standard errors are so large, especially in the lower quintiles, that we cannot reject the null hypothesis of constant returns.

The fact that marginal returns seem to increase with cattle value (at least at higher levels) is a strong indication for the existence of non-convexities in the production technology. Why these non-convexities exist and what they imply for policy is ex-ante less clear. We will turn to this question later and present

\footnotetext{
${ }^{37}$ Figure 2 plots semi-parametric estimates of average returns against parametric estimates and observed outcomes. As we can see, average returns also vary much more at lower cattle values than at higher cattle values.
} 
some robustness checks first.

\subsection{Robustness checks}

As described in Section 3, the estimates presented so far might be biased due to unobserved heterogeneity and attenuation bias. Tables 10 to 12 report the instrumental variable estimates of marginal returns. When calculated in levels, IV estimates of marginal returns are roughly $40 \%$ per year, which is about three times as high as the non-instrumented estimates. If we assume that the production function is a CES function, estimated returns are even higher. We find them to be $64-69 \%$ annually at the mean and about $56-61 \%$ annually in the third quintile of cattle value, income and cost. Although these estimates are quite high, they are in line with findings from de Mel et al. (2008) who compare for a sample of small non-agricultural firms non-experimental and experimental estimates of returns to capital. Their experimental estimates are about twice as high as OLS estimates.

As explained earlier, IV estimates are likely to exceed average estimates of marginal returns because households with high returns to cattle are more likely to use their income from the NREGA to invest in more cattle. In light of observed non-convexities in returns it is also likely that households with access to the NREGA reached above average cattle values where marginal returns are also higher. It thus seems reasonable to assume that the OLS estimates reported in this paper are lower bounds to the population average of marginal returns, whereas the IV estimates are probably the upper bound.

Beyond functional form assumptions, the assumptions we make regarding the production function and its parameters might be influencing estimated outcomes. Allowing fodder inputs to affect output directly, for example, could change our results. The underlying assumption would be that if a household fails to adequately nourish its dairy animals during the pregnancy and milking period, then this is likely to influence the returns on that animal. In order to test this, we also control for fodder expenses during the period of reference in our estimation of profits (not reported here). As expected, the coefficient of the fodder variable is positive $(50 \%)$ and statistically significant in all our specifications. In the linear production function scenario, the coefficient of cattle value drops considerably, from $13 \%$ to $7 \%$ when including fodder expenses. In contrast, in the CES production function, estimated returns increase to $18-20 \%$ when controlling for fodder input. One problem in correctly measuring both returns, is that fodder expenses are highly correlated with animal value and animal value is likely to reflect the feeding practices of households (well nourished animals with high milk output have a higher current value than undernourished animals). The correlation coefficient of both variables is about 0.52 . The logtransformation of both variables reduces the correlation coefficient to roughly 0.17 , which can explain why estimated returns are less affected by the inclusion or exclusion of fodder in the CES functional form.

Finally, we allow returns to vary with rainfall conditions to get more explicit evidence on the role of weather conditions. The coefficient of the interaction term of rainfall and cattle value is positive and statistically significant (see Table 17). At zero rainfall deviation (hence at the 10 year average of annual rainfall), marginal returns are roughly $17 \%$. As expected, returns to cattle increase with higher than average rainfall and fall with lower than average rainfall. 


\section{Explaining the non-convexities: Returns to scale or returns to modern variety cows?}

The results presented so far suggest considerable returns to scale in cattle farming with average returns to cattle only being positive in the highest quintile of the cattle distribution. Marginal returns also increase with cattle value. Lastly, there is some evidence that marginal returns are higher at very low levels of cattle value.

To get a better understanding of this pattern, we estimate different costs and plot them against cattle value (Figure 3). The cost curves are fitted parametrically using the same controls as in the estimation of marginal returns and allowing for a quadratic association between costs and cattle value. Remember that we assume a constant depreciation rate of $20 \%$ per annum. The first graph plots predicted absolute costs, while the second plots average costs.

The cost structure nicely shows why marginal returns are increasing with cattle value. Total costs are roughly INR 2,800 (US\$ 60) at the minimum of cattle value, which is more than twice the corresponding cattle value. Labor costs make up for the main part of total costs, while paid-out costs are about one third of total costs. Depreciation is negligible at this level due to the low value of cattle. Average costs decrease pronouncedly with cattle value up to a cattle value of roughly INR 20,000 (US\$ 431). After that, average costs increase again slightly, reaching almost $50 \%$ of cattle value at the maximum of cattle value. ${ }^{38}$ Average costs are lowest in the range of INR 20,000 to 40,000 (US $\$ 431$ to 862 ). Households in that range own on average 3.5 cows or buffaloes. This suggests that average costs can be minimized with 3-4 animals. Beyond this size, economies of scale seem to play no further role as average costs increase again.

From Figure 1 we know that marginal returns start increasing again as households overcome a threshold of INR 20,000 (US\$ 431). These gains in productivity are achieved despite increasing average costs. Where do these increases in profits come from if not from cost reductions? One explanation can be found in the differences in productivity across animal breeds and value. Because investing in cattle does not only imply acquiring more cattle, but can also mean exchanging animals for more productive breeds, increasing marginal returns can be found even in a range where economies of scale are already fully exploited.

In order test this idea more systematically, we re-estimate average and marginal returns but now split the sample by quintiles of average cattle value (instead of total cattle value) and by animal breed (Tables 13 to 16). ${ }^{39}$ Average returns in the 5 th quintile are $9 \%$ per year even though households in that quintile own only two animals on average. Marginal returns also increase considerably with average cattle value, reaching $15 \%$ in the highest quintile. Again, marginal returns seem to be slightly higher in the lowest quintile than in the

\footnotetext{
${ }^{38}$ With increasing cattle value different costs become more important. While labor costs seem to increase under proportionally, other paid out cost increase over proportionally with cattle value. Average labor cost decreases constantly with cattle value, reaching $6.7 \%$ at the maximum of cattle value.

${ }^{39}$ Average cattle value is the total value of adult cattle reported by the household divided by the number cows and buffaloes. Because we do not have this information at the individual animal level, we use this value as approximation of the average quality and age of these animals.
} 
2nd and 3rd quintiles, but here the differences are much smaller.

Table 14 reports estimates of average returns for different cattle breeds. Our results suggest that modern variety cows, thus imported European breeds and their cross-breeds have the highest average returns, whereas traditional breeds and buffaloes have negative or zero returns. Estimates of marginal returns by cattle breed support this finding. While modern variety cows have marginal returns of roughly $31 \%$, all other varieties have marginal returns close to zero. Similar results can be obtained when looking at semiparametric estimates of marginal returns by cattle breed (see Figure 4). Given that modern variety cows are also the most expensive animals, this suggests that returns to modern variety cows (e.g. returns to acquiring a more productive animal) are at least as important as returns to scale.

The existence of both returns to modern variety breeds and of returns to scale could also explain why we find high (but decreasing) marginal returns at very low levels of cattle value despite negative average returns in that range. In the lowest range of cattle value, average costs fall drastically with small increases in cattle value. Increasing the value of cattle raises costs, but only marginally, while there are productivity gains of increasing cattle value. This causes net gains of increasing cattle value as reflected in positive marginal returns. As cattle value increases further, the reduction in average costs slows down, leading marginal returns to fall and eventually to become zero.

\section{Conclusions}

This paper addresses the apparent puzzle of widespread support of cattle farming by agricultural policy interventions vis-a-vis largely negative returns to cattle as stressed in recent works. To get a more in-depth impression of the profitability of cattle farming, we compare average and marginal returns to cattle at different levels of cattle value and for different breeds in Andhra Pradesh, India. The results of this paper are as follows. We find that average returns to cattle are negative by $2 \%$ on average and vary between large negative rates at low cattle values and positive and considerable rates at high cattle values. Similarly to Attanasio and Augsburg (2014), we find that returns increase considerably with favorable weather conditions. In contrast to average returns, marginal returns to cattle are found to be positive at all levels of cattle value. While average returns increase with cattle value, marginal returns seem to follow a U-shaped pattern, with the highest returns at extremely low and at above average values of cattle. On average, marginal returns are found to range between $13 \%$ and $17 \%$ annually, depending on the specification considered.

These estimates are quite substantial and indicate that investing in cattle could be a viable strategy for households in rural areas of Andhra Pradesh. But we also find strong evidence that herd size and quality matter. The fact that only households operating at large scales as well as households with the highest value animals have positive average returns, suggests that high entry costs prevent many households from operating at profitable levels. These entry barriers would also explain the observed non-convexities in marginal returns.

Two types of entry barriers were identified: first, economies of scale associated with substantial cost savings of owning more than one animal and, second, differences in prices and productivity across cattle breeds. Economies of scale 
might be overcome over time, by choosing not to sell calves and retaining them for future milk production. But exploring returns to modern variety cows might be more challenging. As we saw in Section 3, the average market value of a fertile cross-breed cow is about INR 10,500 (or US\$226), in many cases even considerably higher). In contrast the average value of cows and buffaloes in the sample is roughly INR 6,500 (US\$140), thus just over half this value. That the cattle value in the sample is consistently below reported market prices suggests that most households in our sample might face difficulties in raising the funds to finance the investment in a high value animal. The average household income of non-cattle farmers in the sample is INR 30,700 (US\$ 662) per year. This is less than three times the market value of a cross-breed cow. We saw earlier that marginal returns to cattle are highest above the threshold of INR 20,000 (US\$ 431) of cattle value, which is as much as two thirds of the total annual income of these households. This implies that households have to overcome substantial entry barriers to be able to generate positive returns from cattle farming. This could also explain why many households seem to operate at inefficient levels, e.g. at low cattle values and with negative average returns. If poor households cannot afford buying a high profitability cow, and choose a more affordable but also less productive animal instead, they will be trapped in a low asset value-low productivity cycle, which is difficult to overcome just through re-investing profits. First, these are too low and second, there is evidence that cattle markets are not well functioning in rural India. ${ }^{40}$ Because cattle can be sold at good prices only while it is lactating and at young age, it will hardly be profitable for farmers to sell animals at higher age in order to reinvest in a younger animal. These indivisibilities will force households to accumulate savings over a long time period. This might be very challenging due to highly competing needs within poor households and simply because savings are hard to accumulate in an environment in which shocks occur regularly.

The results of this paper suggest that non-convexities in returns to livestock farming trap poor households in low productivity asset levels. The finding of a 'poverty trap' a la Banerjee and Newman (1993) is in contrast to the findings of the research that focuses on micro and small firms in the manufacturing and service sector (see e.g. Banerjee and Duflo, 2004; McKenzie and Woodruff, 2006; De Mel et al., 2008; Kremer et al., 2010; Grimm et al., 2013; Fafchamps et al., 2014; Dodlova et al., 2014). But it explains why policy interventions to increase investments in cattle seem to fail in rural India as stipulated by Morduch et al. (2013). Households can only reach a level of positive average returns to cattle and enter on a beneficial accumulation path if they overcome considerable entry barriers. This is obviously harder for poorer households who would be the potential beneficiaries of asset-based anti-poverty policies.

In terms of policy implications, the results of this paper suggest, that policies such as the 'One cow per poor family program' or the 'Targeting the Ultra Poor' policy, can only have lasting poverty impacts if the opportunity cost of labor is indeed low in the target group and if beneficiaries are enabled, for instance through credits, to invest enough in the quantity and quality of their cattle ensuring the average profitability to be positive.

\footnotetext{
${ }^{40}$ According to Anagol (2009) markets for cattle are malfunctioning because of the difficulty to assess the productivity of a cow if it is not currently lactating. Moreover, the market for animals beyond the first lactation phase is very thin. Most farmers will seek to buy a cow when the animal has calved for the first time, but not later.
} 


\section{References}

AHD-GAP (2009) Estimates of major livestock product for the years 20082009 \& 2009-2010, Animal Husbandry Department, Government of Andhra Pradesh, Hyderabad, India.

Anagol, S., Etang, A. and Karlan, D. (2013) Continued Existence of Cows Disproves Central Tenets of Capitalism?, NBER Working Paper No. 19437, National Bureau of Economic Research, Cambridge, USA.

Angrist, J. and Pischke, J.-S. (2009) Mostly harmless econometrics: an empiricists companion, Princeton University Press, Princeton, USA.

Attanasio, O. and Augsburg, B. (2014) Holy cows or cash cows?, NBER Working Paper No. 20304, National Bureau of Economic Research, Cambridge, USA.

Banerjee, A. V. and Duflo, E. (2004) Do firms want to borrow more?: Testing credit constraints using a directed lending program, Working Paper, Centre for Economic Policy Research, London, UK.

Banerjee, A. V. and Newman, A. F. (1993) Occupational choice and the process of development, Journal of Political Economy, 101, 274-298.

Belsley, D. A., Kuh, E. and Welsch, R. E. (1980) Regression diagnostics: Identifying influential observations and sources of collinearity, John Wiley and Sons, New York, USA.

De Mel, S., McKenzie, D. J. and Woodruff, C. (2008) Returns to capital in microenterprises: Evidence from a field experiment, Quarterly Journal of Economics, 123, 1329-1372.

Dodlova, M., Goebel, K., Grimm, M. and Lay, J. (2014) Constrained firms, not subsistence activities: Evidence on capital returns and accumulation in Peruvian microenterprises, revised version of IZA Discussion Paper No. 6866, IZA, Bonn.

Fafchamps, M., McKenzie, D., Quinn, S. and Woodruff, C. (2014) Microenterprise growth and the flypaper effect: Evidence from a randomized experiment in Ghana, Journal of Development Economics, 106, 211-226.

Galab, S., Vijay Kumar, S., Prudvikhar Reddy, P., Singh, R. and Vennam, U. (2011) The Impact of Growth on Childhood Poverty in Andhra Pradesh: Initial Findings from India, Young Lives Round 3 Survey Report: India, University of Oxford.

Ghule, A. K., Verma, N. K., Cahuhan, A. K. and Sawale, P. (2012) An economic analysis of investment pattern, cost of milk production and profitability of commercial dairy farms in maharashtra, Indian Journal of Dairy Science, 65, 329-336.

Grimm, M., Hartwig, R. and Lay, J. (2013) Does forced solidarity hamper investment in small and micro enterprises?, IZA Discussion Paper No. 7229, IZA, Bonn (revised version: Insurance, Informal Taxation and Investment). 
Grimm, M., Krueger, J. and Lay, J. (2011) Barriers to entry and returns to capital in informal activities: Evidence from sub-saharan africa, Review of Income and Wealth, 57, S27-S53.

Harrell, F. E. (2001) Regression modeling strategies: with applications to linear models, logistic regression, and survival analysis, Springer, New York, USA.

Kremer, M., Lee, J. N., Robinson, J. M. and Rostapshova, O. (2010) The return to capital for small retailers in Kenya: Evidence from inventories, Mimeo, Harvard University.

McKenzie, D. J. and Woodruff, C. (2006) Do entry costs provide an empirical basis for poverty traps? evidence from mexican microenterprises, Economic Development and Cultural Change, 55, 3-42.

Morduch, J., Ravi, S. and Bauchet, J. (2013) Substitution Bias and External Validity: Why an Innovative Anti-poverty Program Showed no Net Impact, Working Paper No. 2013-03, Institute of Economic Research, Hitotsubashi University.

Mukasa-Mugerwa, E. (1989) A review of a productive performance of female Bos indicus (zebu) cattle, International Livestock Centre for Africa (ILCA).

Protos, J., Morandini, F., Sheikh, M. and Kanyandekwe, C. (2011) One Cow per Poor Family: Reaching the most marginalized in Rwanda, UNICEF, New York, USA.

Rosenzweig, M. R. and Wolpin, K. I. (1993) Credit market constraints, consumption smoothing, and the accumulation of durable production assets in low-income countries: Investment in bullocks in india, Journal of Political Economy, 101, 223-244.

Royston, P. and Sauerbrei, W. (2007) Multivariable modeling with cubic regression splines: a principled approach, Stata Journal, 7, 45-70.

Ruvuna, F., Mao, I., McDowell, R. and Gurnani, M. (1984) Environmental and genetic variation in milk yield of native cattle and crosses with brown swiss in india, Journal of Animal Science, 59, 74-85.

Swanepoel, F., Stroebel, A. and Moyo, S. (2010) The Role of Livestock in Developing Communities: Enhancing Multifunctionality, The Technical Centre for Agricultural and Rural Cooperation (CTA), Wageningen, The Netherlands. 


\section{A Figures}

Figure 1: Semiparametric estimation of marginal returns to cattle
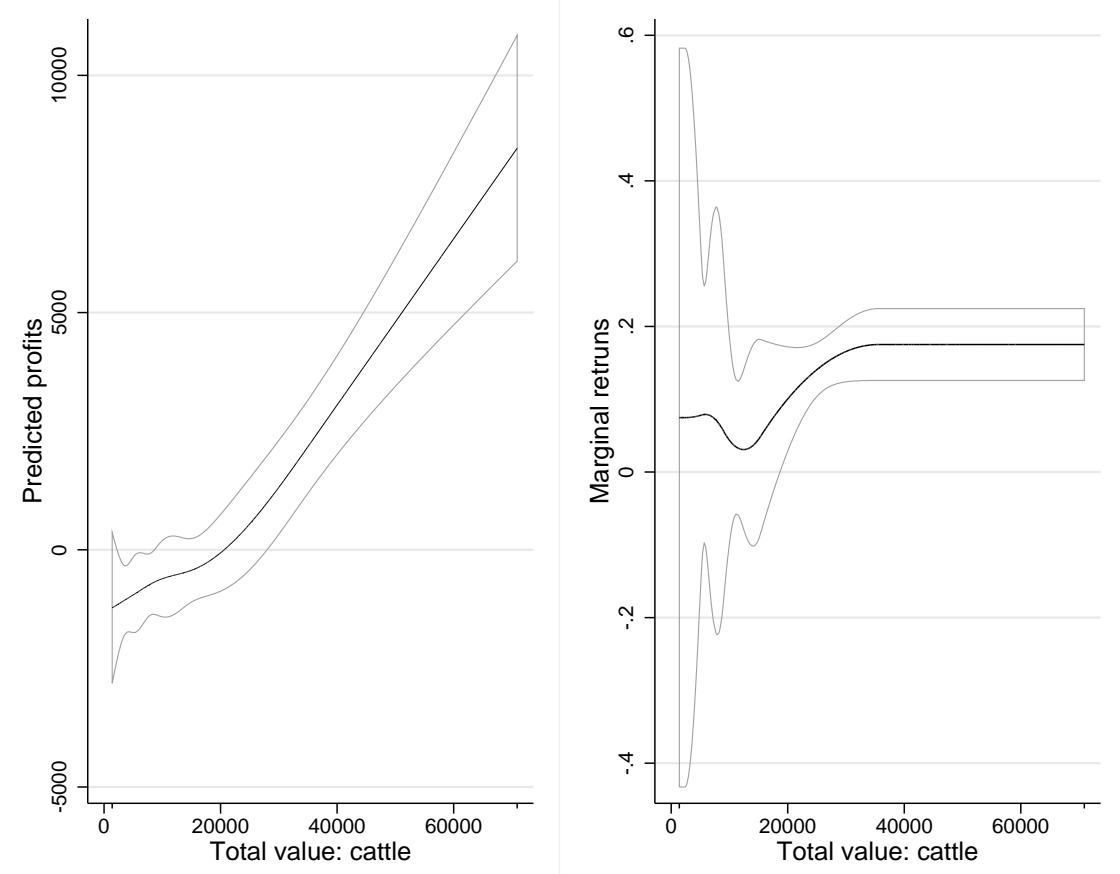

$90 \%$ confidence intervals

Restricted cubic splines, 5 knots 
Figure 2: Average returns to cattle

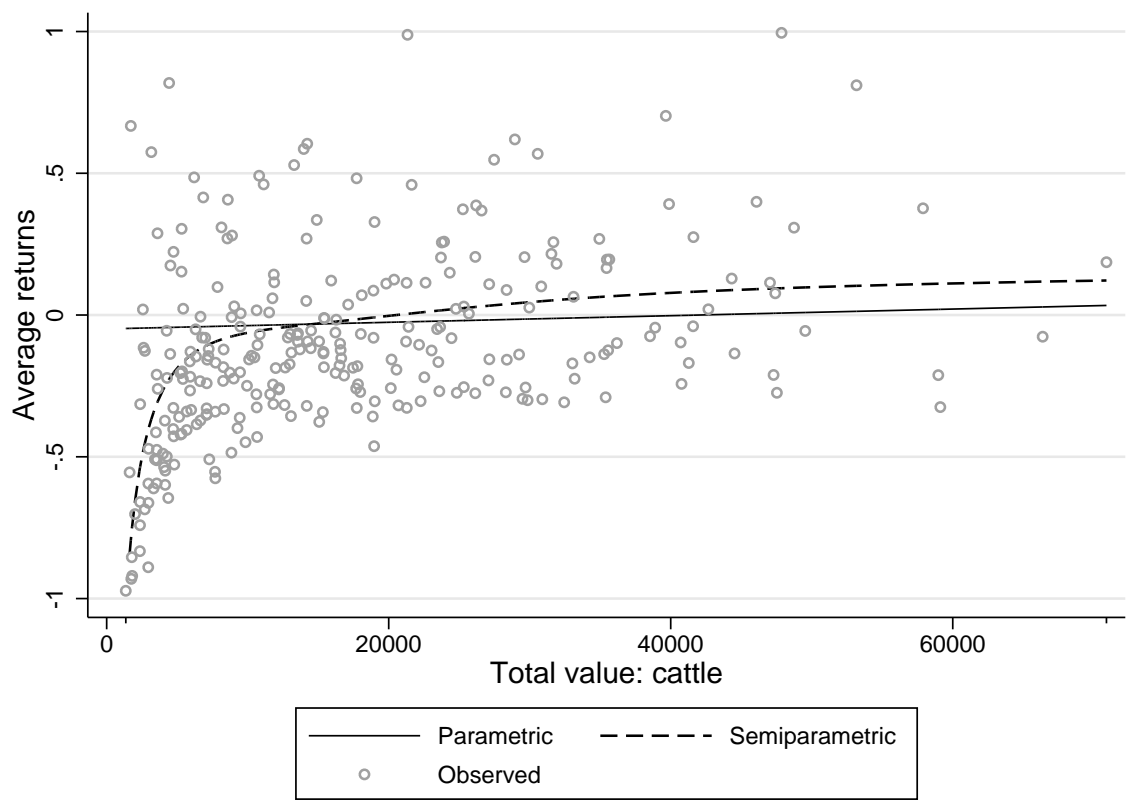

Figure 3: Cost structure
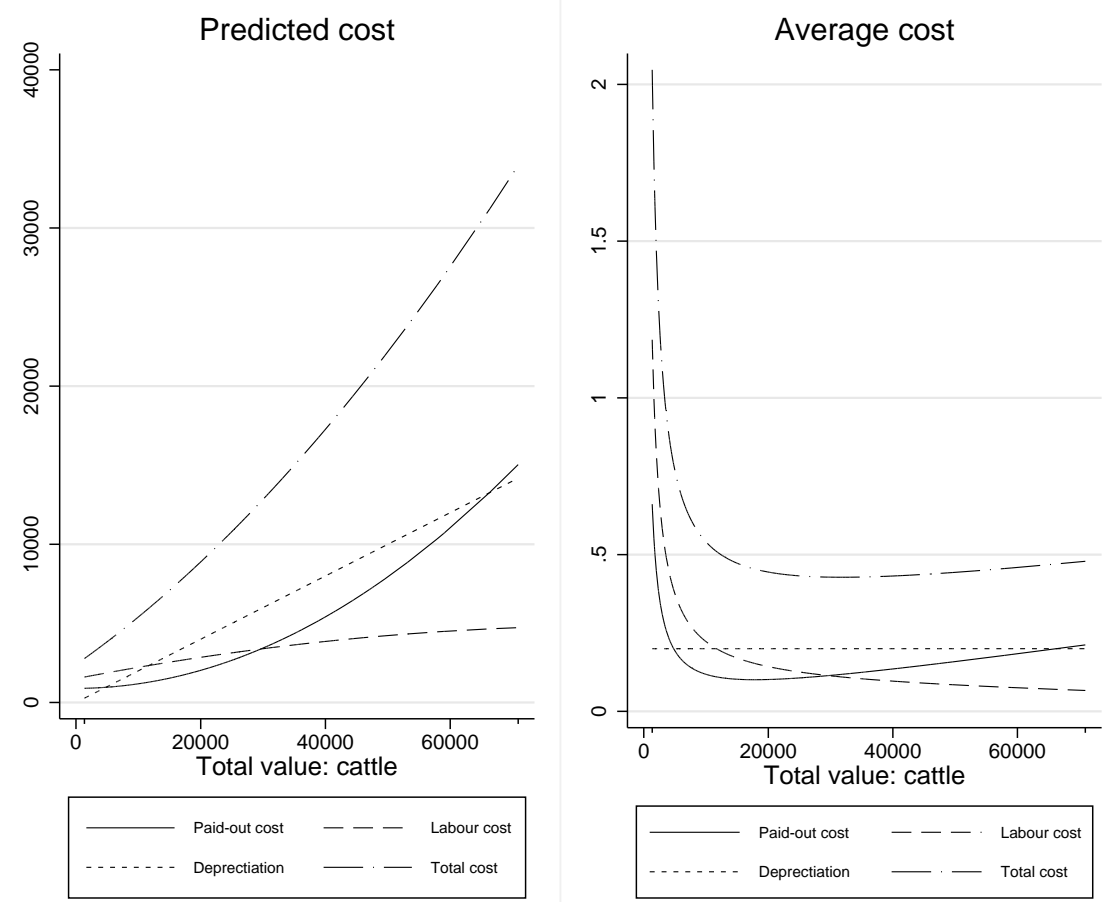
Figure 4: Semiparametric estimation of marginal returns to cattle by breed
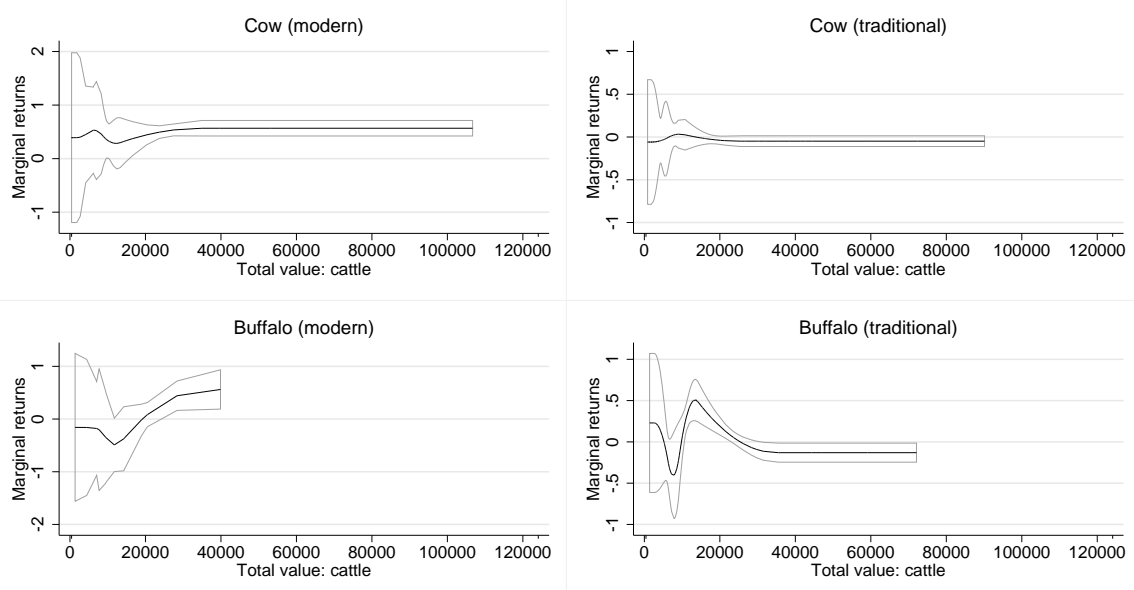

$90 \%$ confidence intervals

Restricted cubic splines, 5 knots

\section{B Tables}




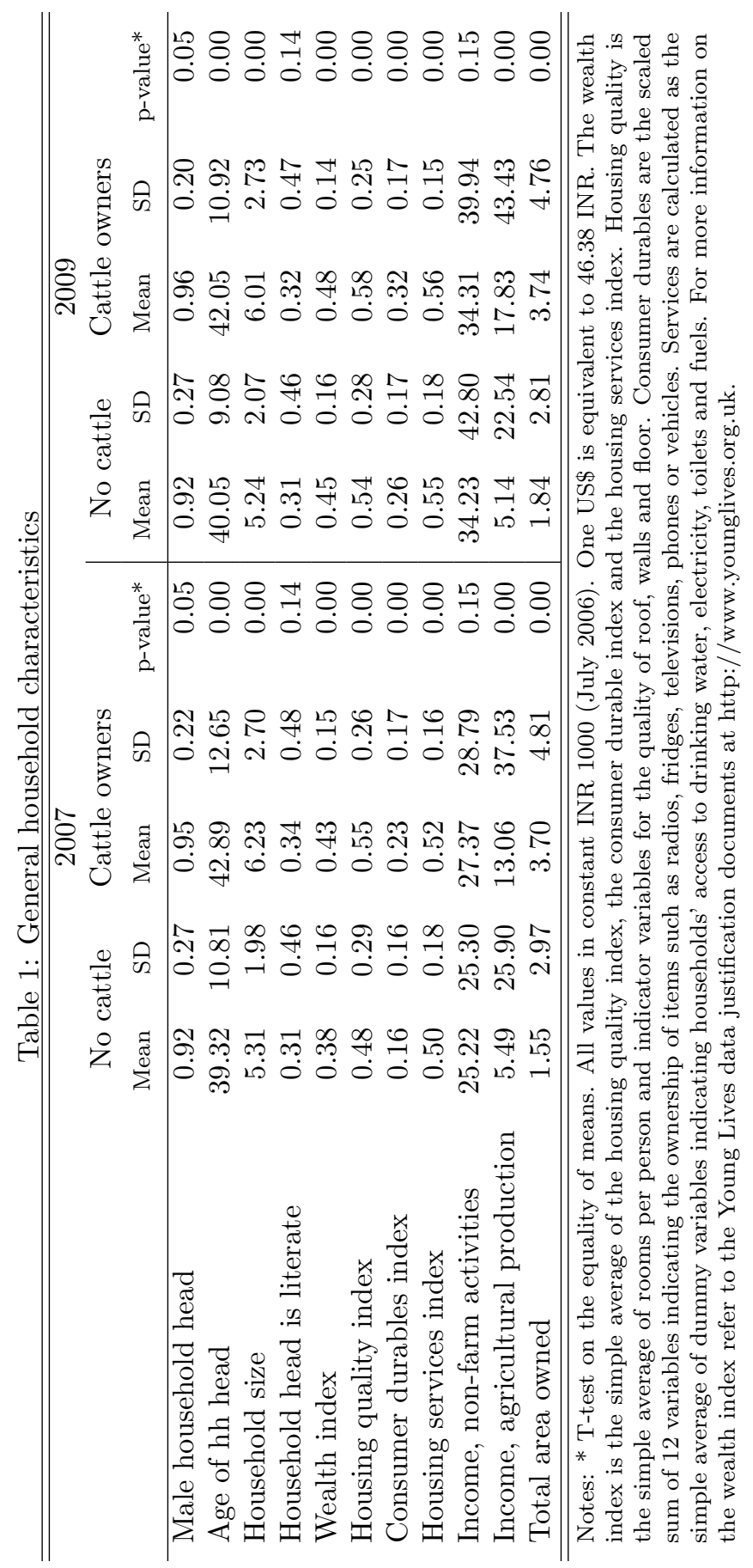


Table 2: Farming characteristics

\begin{tabular}{lrrrr}
\hline \hline & \multicolumn{2}{c}{2007} & \multicolumn{2}{c}{2009} \\
& Mean & \multicolumn{1}{c}{ SD } & \multicolumn{1}{c}{ Mean } & \multicolumn{1}{c}{ SD } \\
\hline Total value: cattle & 12152.9 & $(12524.4)$ & 13624.5 & $(13064.1)$ \\
Quantity: cattle & 1.97 & $(1.47)$ & 1.96 & $(1.47)$ \\
Quantity owned: Cow (modern) & 0.17 & $(0.68)$ & 0.26 & $(0.61)$ \\
Quantity owned: Cow (traditional) & 0.78 & $(1.18)$ & 0.83 & $(1.28)$ \\
Quantity owned: Buffalo (modern) & 0.19 & $(0.62)$ & 0.11 & $(0.53)$ \\
Quantity owned: Buffalo (traditional) & 0.82 & $(1.29)$ & 0.75 & $(1.23)$ \\
Average cattle value & 6079.8 & $(4117.7)$ & 6832.1 & $(3442.0)$ \\
Total value: calves & 815.8 & $(1369.5)$ & 2244.5 & $(3627.8)$ \\
Quantity: calves & 0.95 & $(1.14)$ & 1.35 & $(1.34)$ \\
Total earnings from sale of dairy products & 3599.2 & $(9003.3)$ & 6187.1 & $(10780.7)$ \\
Cost from sale of dairy products (excl. labor) & 1380.2 & $(4562.9)$ & 2243.4 & $(4281.5)$ \\
Expenditure on cattle: veterinary & 205.5 & $(471.7)$ & 232.5 & $(624.3)$ \\
Expenditure on cattle: fodder & 1801.8 & $(4138.7)$ & 1550.1 & $(2994.0)$ \\
Expenditure on cattle: other cost & 32.4 & $(148.4)$ & 74.8 & $(195.4)$ \\
Total expenditure on cattle & 2039.7 & $(4449.5)$ & 1857.4 & $(3224.9)$ \\
Time spent on cattle (hours per year) & 450.2 & $(190.3)$ & 486.4 & $(199.6)$ \\
Shock affected livestock & 0.13 & $(0.33)$ & 0.19 & $(0.39)$ \\
Rainfall (deviation) & -0.26 & $(0.24)$ & 0.00 & $(0.24)$ \\
\hline \hline
\end{tabular}

Notes: All values in constant INR 1000 (July 2006). One US\$ is equivalent to 46.38 INR. 


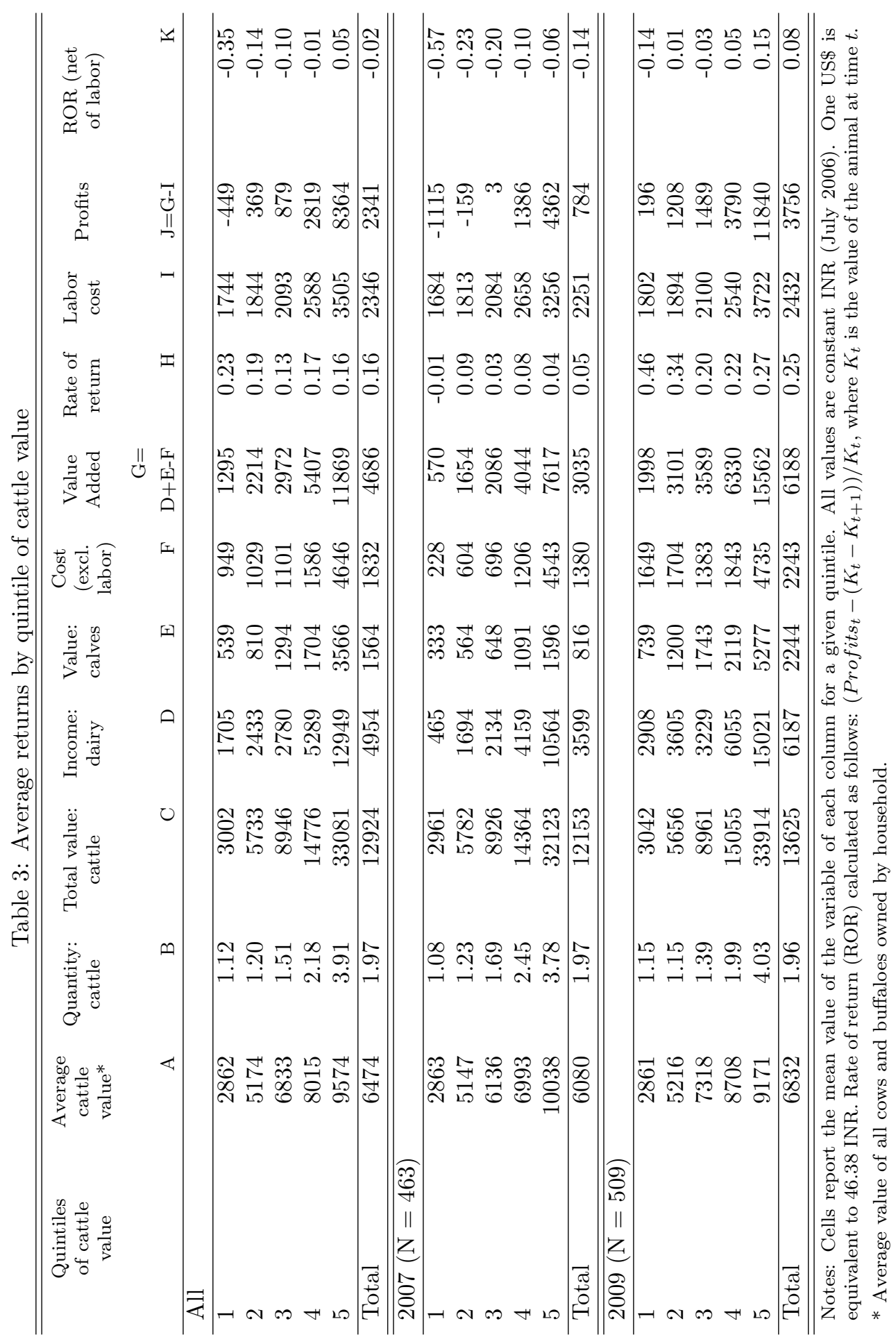




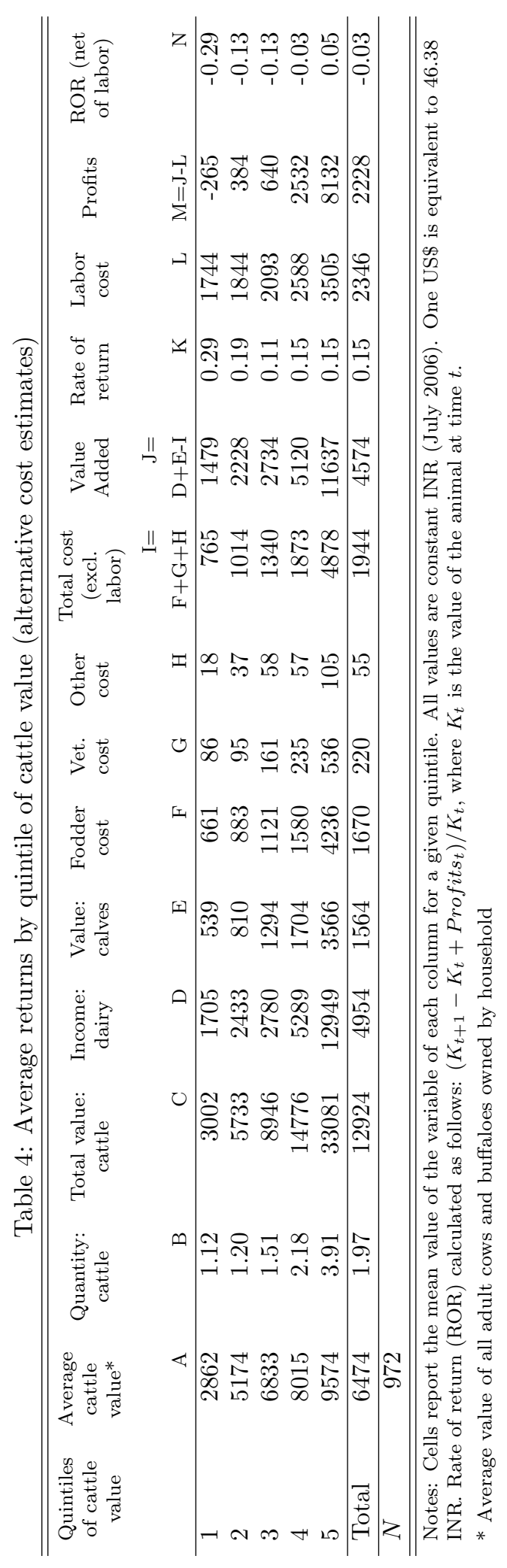


Table 5: Estimated profits from dairy production

\begin{tabular}{|c|c|c|c|c|c|}
\hline & \multirow{2}{*}{$\begin{array}{l}2007 \text { OLS } \\
\text { (1) }\end{array}$} & \multicolumn{2}{|c|}{ Pooled OLS } & \multirow{2}{*}{$\begin{array}{l}\mathrm{RE} \\
(4)\end{array}$} & \multirow{2}{*}{$\begin{array}{l}\mathrm{FE} \\
(5)\end{array}$} \\
\hline & & $(2)$ & $(3)$ & & \\
\hline Total value: cattle & $\begin{array}{l}0.030 \\
(0.074)\end{array}$ & $\begin{array}{l}0.125^{+} \\
(0.063)\end{array}$ & $\begin{array}{c}0.046 \\
(0.065)\end{array}$ & $\begin{array}{l}0.125^{*} \\
(0.063)\end{array}$ & $\begin{array}{c}0.043 \\
(0.072)\end{array}$ \\
\hline Total value: cattle (squared) & & & $\begin{array}{c}0.000 \\
(0.000)\end{array}$ & & \\
\hline Time spent on cattle (hrs / year) & $\begin{array}{c}-5.875^{* * *} \\
(0.990)\end{array}$ & & & & \\
\hline Time spent on cattle (squared) & $\begin{array}{l}0.001^{*} \\
(0.001)\end{array}$ & & & & \\
\hline Total area owned & $\begin{array}{c}-148.757^{*} \\
(62.718)\end{array}$ & $\begin{array}{c}-169.559^{*} \\
(70.428)\end{array}$ & $\begin{array}{c}-154.663^{*} \\
(65.442)\end{array}$ & $\begin{array}{c}-169.559^{*} \\
(70.428)\end{array}$ & $\begin{array}{c}50.517 \\
(102.604)\end{array}$ \\
\hline Household size & $\begin{array}{l}-84.765 \\
(88.163)\end{array}$ & $\begin{array}{c}-112.145^{+} \\
(62.251)\end{array}$ & $\begin{array}{l}-101.750 \\
(63.509)\end{array}$ & $\begin{array}{c}-112.145^{+} \\
(62.251)\end{array}$ & $\begin{array}{c}396.099 \\
(326.125)\end{array}$ \\
\hline Male & $\begin{array}{l}-797.046 \\
(512.278)\end{array}$ & $\begin{array}{c}-1512.328^{* *} \\
(543.937)\end{array}$ & $\begin{array}{c}-1544.287^{* *} \\
(560.978)\end{array}$ & $\begin{array}{c}-1512.328^{* *} \\
(543.937)\end{array}$ & $\begin{array}{c}-10441.049^{* * *} \\
(2414.332)\end{array}$ \\
\hline Age & $\begin{array}{l}-13.661 \\
(17.086)\end{array}$ & $\begin{array}{c}11.411 \\
(19.900)\end{array}$ & $\begin{array}{l}10.505 \\
(20.051)\end{array}$ & $\begin{array}{c}11.411 \\
(19.900)\end{array}$ & $\begin{array}{l}-55.127 \\
(50.575)\end{array}$ \\
\hline Grade & $\begin{array}{c}116.955^{+} \\
(68.422)\end{array}$ & $\begin{array}{c}192.342^{* *} \\
(63.718)\end{array}$ & $\begin{array}{c}186.233^{* *} \\
(60.981)\end{array}$ & $\begin{array}{c}192.342^{* *} \\
(63.718)\end{array}$ & $\begin{array}{c}296.035 \\
(221.830)\end{array}$ \\
\hline Wealth index & $\begin{array}{c}2318.693 \\
(1844.843)\end{array}$ & $\begin{array}{c}1281.043 \\
(1797.000)\end{array}$ & $\begin{array}{c}1158.516 \\
(1794.525)\end{array}$ & $\begin{array}{c}1281.043 \\
(1797.000)\end{array}$ & $\begin{array}{c}2174.081 \\
(3668.028)\end{array}$ \\
\hline Shock affected livestock & $\begin{array}{l}-402.410 \\
(865.903)\end{array}$ & $\begin{array}{c}141.884 \\
(819.901)\end{array}$ & $\begin{array}{c}247.256 \\
(896.583)\end{array}$ & $\begin{array}{c}141.884 \\
(819.901)\end{array}$ & $\begin{array}{c}537.761 \\
(1282.777)\end{array}$ \\
\hline Rainfall (deviation) & $\begin{array}{l}-1769.620 \\
(1256.831)\end{array}$ & $\begin{array}{c}1613.694^{+} \\
(844.716)\end{array}$ & $\begin{array}{c}1470.866^{+} \\
(815.700)\end{array}$ & $\begin{array}{c}1613.694^{+} \\
(844.716)\end{array}$ & $\begin{array}{l}3050.843^{* *} \\
(1041.134)\end{array}$ \\
\hline Year 2009 (dummy) & & $\begin{array}{c}2294.661^{* * *} \\
(386.846)\end{array}$ & $\begin{array}{c}2381.635^{* * *} \\
(408.405)\end{array}$ & $\begin{array}{c}2294.661^{* * *} \\
(386.846)\end{array}$ & $\begin{array}{c}2464.570^{* * *} \\
(630.047)\end{array}$ \\
\hline Constant & $\begin{array}{c}262.418 \\
(916.264) \\
\end{array}$ & $\begin{array}{l}-1969.248 \\
(1322.073) \\
\end{array}$ & $\begin{array}{l}-1405.650 \\
(1098.839) \\
\end{array}$ & $\begin{array}{l}-1969.248 \\
(1322.073)\end{array}$ & $\begin{array}{c}4197.727 \\
(4062.948)\end{array}$ \\
\hline Observations & 463 & 972 & 972 & 972 & 972 \\
\hline
\end{tabular}


Table 6: Estimated income from dairy production $(\operatorname{logs})$

\begin{tabular}{|c|c|c|c|c|}
\hline & $\begin{array}{c}2007 \text { OLS } \\
\text { (1) }\end{array}$ & $\begin{array}{c}\text { Pooled OLS } \\
(2)\end{array}$ & $\begin{array}{l}\mathrm{RE} \\
(3)\end{array}$ & $\begin{array}{l}\text { FE } \\
(4)\end{array}$ \\
\hline Total value: cattle (log) & $\begin{array}{c}0.906^{* *} \\
(0.269)\end{array}$ & $\begin{array}{c}0.989^{* * *} \\
(0.153)\end{array}$ & $\begin{array}{c}0.938^{* * *} \\
(0.151)\end{array}$ & $\begin{array}{c}0.187 \\
(0.242)\end{array}$ \\
\hline Time spent on cattle (hours per year, log) & $\begin{array}{l}0.120^{*} \\
(0.054)\end{array}$ & & & \\
\hline Total land owned (acres, log) & $\begin{array}{l}-0.365 \\
(0.261)\end{array}$ & $\begin{array}{l}-0.212 \\
(0.181)\end{array}$ & $\begin{array}{l}-0.166 \\
(0.184)\end{array}$ & $\begin{array}{c}0.048 \\
(0.394)\end{array}$ \\
\hline Household size & $\begin{array}{c}-0.177^{* *} \\
(0.064)\end{array}$ & $\begin{array}{l}-0.045 \\
(0.036)\end{array}$ & $\begin{array}{c}-0.044 \\
(0.036)\end{array}$ & $\begin{array}{c}0.229 \\
(0.164)\end{array}$ \\
\hline Male & $\begin{array}{c}-0.918^{* *} \\
(0.340)\end{array}$ & $\begin{array}{c}-1.104^{* * *} \\
(0.233)\end{array}$ & $\begin{array}{c}-1.092^{* * *} \\
(0.237)\end{array}$ & $\begin{array}{c}0.190 \\
(1.817)\end{array}$ \\
\hline Age & $\begin{array}{l}0.024^{+} \\
(0.013)\end{array}$ & $\begin{array}{c}0.012 \\
(0.008)\end{array}$ & $\begin{array}{c}0.011 \\
(0.008)\end{array}$ & $\begin{array}{r}-0.080^{+} \\
(0.045)\end{array}$ \\
\hline Grade & $\begin{array}{c}0.039 \\
(0.044)\end{array}$ & $\begin{array}{c}0.093^{* *} \\
(0.032)\end{array}$ & $\begin{array}{c}0.089^{* *} \\
(0.033)\end{array}$ & $\begin{array}{r}-0.183^{+} \\
(0.110)\end{array}$ \\
\hline Wealth index & $\begin{array}{c}1.306 \\
(1.079)\end{array}$ & $\begin{array}{l}-0.431 \\
(0.799)\end{array}$ & $\begin{array}{l}-0.372 \\
(0.808)\end{array}$ & $\begin{array}{c}2.168 \\
(2.302)\end{array}$ \\
\hline Shock affected livestock & $\begin{array}{c}1.301^{* * *} \\
(0.373)\end{array}$ & $\begin{array}{c}0.798^{* * *} \\
(0.199)\end{array}$ & $\begin{array}{c}0.786^{* * *} \\
(0.189)\end{array}$ & $\begin{array}{l}0.560^{+} \\
(0.303)\end{array}$ \\
\hline Rainfall (deviation) & $\begin{array}{c}-1.450^{+} \\
(0.754)\end{array}$ & $\begin{array}{c}0.032 \\
(0.440)\end{array}$ & $\begin{array}{c}0.021 \\
(0.431)\end{array}$ & $\begin{array}{c}0.299 \\
(0.502)\end{array}$ \\
\hline Year 2009 (dummy) & & $\begin{array}{c}1.790^{* * *} \\
(0.217)\end{array}$ & $\begin{array}{c}1.801^{* * *} \\
(0.215)\end{array}$ & $\begin{array}{c}1.599^{* * * *} \\
(0.276)\end{array}$ \\
\hline Constant & $\begin{array}{l}-2.674 \\
(2.356)\end{array}$ & $\begin{array}{c}-2.394^{+} \\
(1.348)\end{array}$ & $\begin{array}{l}-2.013 \\
(1.328) \\
\end{array}$ & $\begin{array}{l}5.324^{+} \\
(3.098)\end{array}$ \\
\hline Observations & 463 & 972 & 972 & 972 \\
\hline
\end{tabular}

Table 7: Marginal returns to cattle (logs)

\begin{tabular}{llr}
\hline \hline Quintiles ${ }^{*}$ & \multicolumn{2}{c}{ Marginal returns } \\
\hline$\alpha=$ & 0.94 & 0.99 \\
\hline 1 & 0.18 & 0.22 \\
2 & 0.15 & 0.18 \\
3 & 0.10 & 0.13 \\
4 & 0.14 & 0.16 \\
5 & 0.13 & 0.15 \\
\hline Mean & 0.13 & 0.16 \\
\hline \hline
\end{tabular}

* Quintiles of cattle value. 
Table 8: Marginal returns to cattle by quintiles of total cattle value

\begin{tabular}{lc}
\hline \hline & $(1)$ \\
\hline 1. Quintile & 0.214 \\
& $(0.513)$
\end{tabular}

2. Quintile $\quad 0.242$

$(0.301)$

3. Quintile 0.101

$(0.188)$

4. Quintile 0.114

$(0.114)$

5. Quintile

0.132

$(0.082)$

$N \quad 972$

Notes: Pooled OLS. Clustered std. errors in parentheses.

Controls are those of main model. Cells report average marginal effects of cattle value. ${ }^{*} p<0.05,{ }^{* *} p<0.01$, *** $p<0.001$ 
Table 9: Effect of the NREGA on investment in cattle (first stage)

\begin{tabular}{|c|c|c|c|c|}
\hline & $\begin{array}{l}\text { Pooled OLS } \\
\text { (1) }\end{array}$ & $\begin{array}{l}\mathrm{RE} \\
(2)\end{array}$ & $\begin{array}{c}\text { Pooled OLS } \\
(3)\end{array}$ & $\begin{array}{l}\mathrm{RE} \\
(4)\end{array}$ \\
\hline NREGA introduced in district & $\begin{array}{l}7312.154^{* *} \\
(2162.503)\end{array}$ & $\begin{array}{l}5693.630^{* *} \\
(1978.776)\end{array}$ & & \\
\hline Cumulative expend. NREGA & & & $\begin{array}{l}439.167^{* *} \\
(133.075)\end{array}$ & $\begin{array}{l}342.701^{* *} \\
(122.460)\end{array}$ \\
\hline Total area owned & $\begin{array}{l}404.732^{* *} \\
(136.875)\end{array}$ & $\begin{array}{c}411.652^{* * *} \\
(124.709)\end{array}$ & $\begin{array}{l}402.324^{* *} \\
(136.861)\end{array}$ & $\begin{array}{c}409.745^{* * *} \\
(124.413)\end{array}$ \\
\hline Household size & $\begin{array}{l}327.661^{*} \\
(160.613)\end{array}$ & $\begin{array}{c}319.145 \\
(179.500)\end{array}$ & $\begin{array}{l}331.190^{*} \\
(160.658)\end{array}$ & $\begin{array}{c}321.816 \\
(179.568)\end{array}$ \\
\hline Male & $\begin{array}{c}202.041 \\
(1097.285)\end{array}$ & $\begin{array}{c}34.103 \\
(1071.890)\end{array}$ & $\begin{array}{c}169.621 \\
(1096.720)\end{array}$ & $\begin{array}{c}12.024 \\
(1071.106)\end{array}$ \\
\hline Age & $\begin{array}{c}21.818 \\
(32.457)\end{array}$ & $\begin{array}{c}26.245 \\
(32.882)\end{array}$ & $\begin{array}{c}21.059 \\
(32.410)\end{array}$ & $\begin{array}{c}25.647 \\
(32.835)\end{array}$ \\
\hline Grade & $\begin{array}{c}183.852 \\
(198.005)\end{array}$ & $\begin{array}{c}217.828 \\
(201.067)\end{array}$ & $\begin{array}{c}180.045 \\
(198.407)\end{array}$ & $\begin{array}{c}214.788 \\
(201.459)\end{array}$ \\
\hline Wealth index & $\begin{array}{c}3838.431 \\
(4784.212)\end{array}$ & $\begin{array}{c}3622.304 \\
(4159.004)\end{array}$ & $\begin{array}{c}3898.643 \\
(4816.717)\end{array}$ & $\begin{array}{c}3676.248 \\
(4177.403)\end{array}$ \\
\hline Shock affected livestock & $\begin{array}{c}4029.566^{* * *} \\
(1044.378)\end{array}$ & $\begin{array}{l}3153.094^{* *} \\
(1118.998)\end{array}$ & $\begin{array}{c}4086.522^{* * *} \\
(1049.860)\end{array}$ & $\begin{array}{l}3197.114^{* *} \\
(1125.019)\end{array}$ \\
\hline Rainfall (deviation) & $\begin{array}{c}-8894.527^{* *} \\
(2871.353)\end{array}$ & $\begin{array}{c}-6905.795^{* *} \\
(2458.263)\end{array}$ & $\begin{array}{c}-9043.748^{* *} \\
(2917.936)\end{array}$ & $\begin{array}{c}-6993.816^{* *} \\
(2497.717)\end{array}$ \\
\hline Year 2009 (dummy) & $\begin{array}{l}-1876.390 \\
(1324.077)\end{array}$ & $\begin{array}{c}-849.530 \\
(1160.258)\end{array}$ & $\begin{array}{l}-1722.105 \\
(1295.000)\end{array}$ & $\begin{array}{c}-743.628 \\
(1143.913)\end{array}$ \\
\hline Constant & $\begin{array}{c}2457.383 \\
(2805.574)\end{array}$ & $\begin{array}{c}2833.672 \\
(2432.553)\end{array}$ & $\begin{array}{c}2441.123 \\
(2825.389)\end{array}$ & $\begin{array}{c}2821.894 \\
(2445.900)\end{array}$ \\
\hline Observations & 975 & 975 & 975 & 975 \\
\hline
\end{tabular}

Notes: Clustered standard errors in parentheses. Dep. var: Total value: cattle. Age, sex and grade of main person responsible for livestock. ${ }^{*} p<0.05,{ }^{* *} p<0.01,{ }^{* * *} p<0.001$ 
Table 10: Instrumental variable estimates of marg. returns to cattle (levels)

\begin{tabular}{lcccc}
\hline \hline \multicolumn{2}{l}{ Real profits (adj. for labour) - depreciation (levels) } & & \\
& $(1)$ & $(2)$ & $(3)$ & $(4)$ \\
\hline Total value: cattle & $0.492^{* * *}$ & $0.420^{* * *}$ & $0.489^{* * *}$ & $0.405^{* * *}$ \\
& $(0.132)$ & $(0.106)$ & $(0.134)$ & $(0.106)$
\end{tabular}

First stage coefficient:

NREGA introduced in district $\quad 6158.798^{* * *} \quad 7312.154^{* *}$

(1355.619) (2162.503)

Cumulative expend. NREGA

$357.422^{* * *} \quad 439.167^{* *}$

(82.439) (133.075)

$\begin{array}{lllll}\text { Time dummy } & \text { Yes } & \text { Yes } & \text { Yes } & \text { Yes }\end{array}$

$\begin{array}{lllll}\text { Controls } & \text { No } & \text { Yes } & \text { No } & \text { Yes }\end{array}$

$\begin{array}{llllr}\text { Observations } & 972 & 972 & 972 & 972\end{array}$

$\begin{array}{lrrrr}\text { F statistic } & 20.640 & 11.433 & 18.797 & 10.891\end{array}$

Notes: Clustered standard errors in parentheses Controls: owned land; household size; age, sex, education of person resp. for livestock; wealth; shocks. F statistic is Kleibergen-Paap Wald rk F statistic in the first stage regression. ${ }^{+} p<0.10,{ }^{*} p<0.05,{ }^{* *} p<0.01,{ }^{* * *} p<0.001$

Table 11: Instrumental variable estimates of income from cattle Real income from sale of dairy products \& calves (logs)

\begin{tabular}{lcccc} 
& $(1)$ & $(2)$ & $(3)$ & $(4)$ \\
\hline Total value: cattle $(\log )$ & $2.383^{* * *}$ & $1.977^{* * *}$ & $2.515^{* * *}$ & $2.088^{* * *}$ \\
& $(0.651)$ & $(0.590)$ & $(0.688)$ & $(0.602)$
\end{tabular}

First stage coefficient:

NREGA introduced in district $0.587^{* * *} \quad 0.678^{* * *}$

$(0.095) \quad(0.146)$

Cumulative expend. NREGA

$$
\begin{array}{cc}
0.034^{* * *} & 0.041^{* * *} \\
(0.006) & (0.009)
\end{array}
$$

\begin{tabular}{lcccc} 
Time dummy & Yes & Yes & Yes & Yes \\
Controls & No & Yes & No & Yes \\
\hline Observations & 972 & 972 & 972 & 972 \\
F statistic & 37.910 & 21.687 & 31.950 & 19.813 \\
\hline \hline
\end{tabular}

Notes: Clustered standard errors in parentheses. Controls: land; household size; age, sex, education of person resp. for livestock; wealth; shocks. F statistic is Kleibergen-Paap Wald rk F statistic in the first stage regression. ${ }^{+} p<0.10,{ }^{*} p<0.05,{ }^{* *} p<0.01,{ }^{* * *} p<0.001$ 
Table 12: IV estimates of marg. returns to cattle by quintile (logs)

\begin{tabular}{lll}
\hline \hline Quintiles* & \multicolumn{2}{c}{ Marginal returns } \\
\hline$\alpha=$ & 1.98 & 2.09 \\
\hline 1 & 0.96 & 1.05 \\
2 & 0.74 & 0.80 \\
3 & 0.58 & 0.63 \\
4 & 0.63 & 0.68 \\
5 & 0.65 & 0.70 \\
\hline Mean & 0.66 & 0.71 \\
\hline \hline \multicolumn{2}{l}{ * Quintiles of cattle value, income and }
\end{tabular}

cost. 


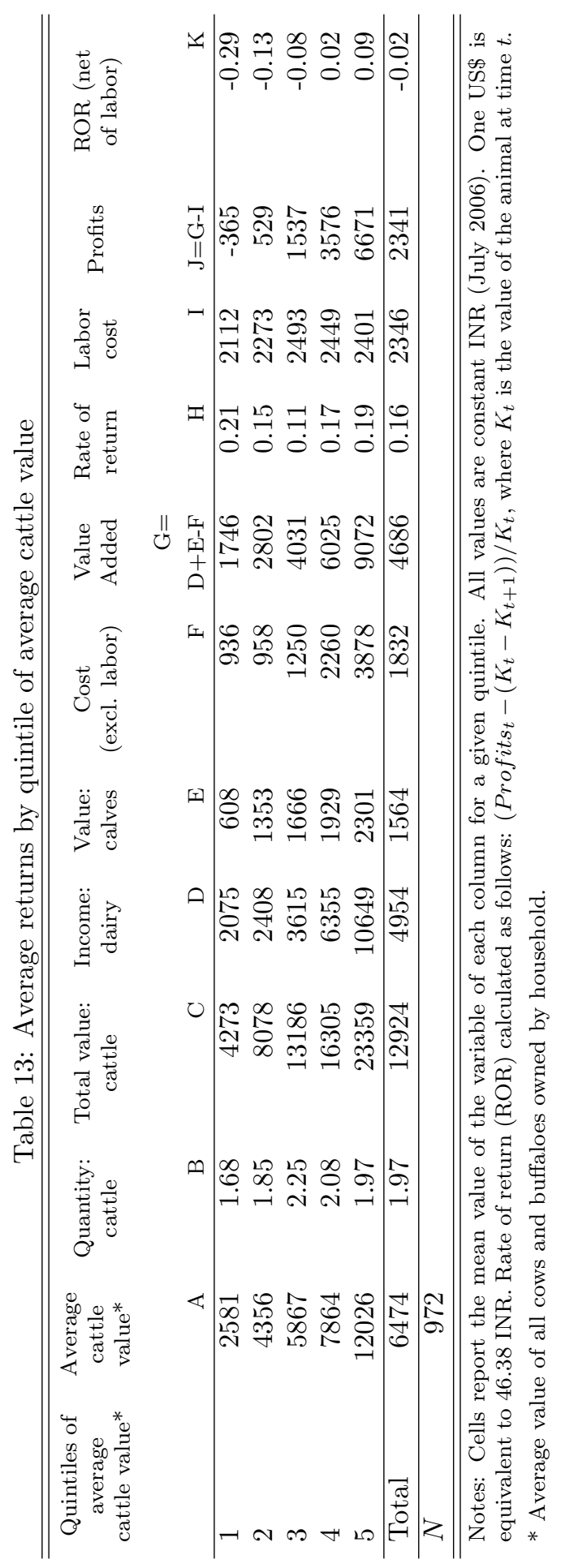




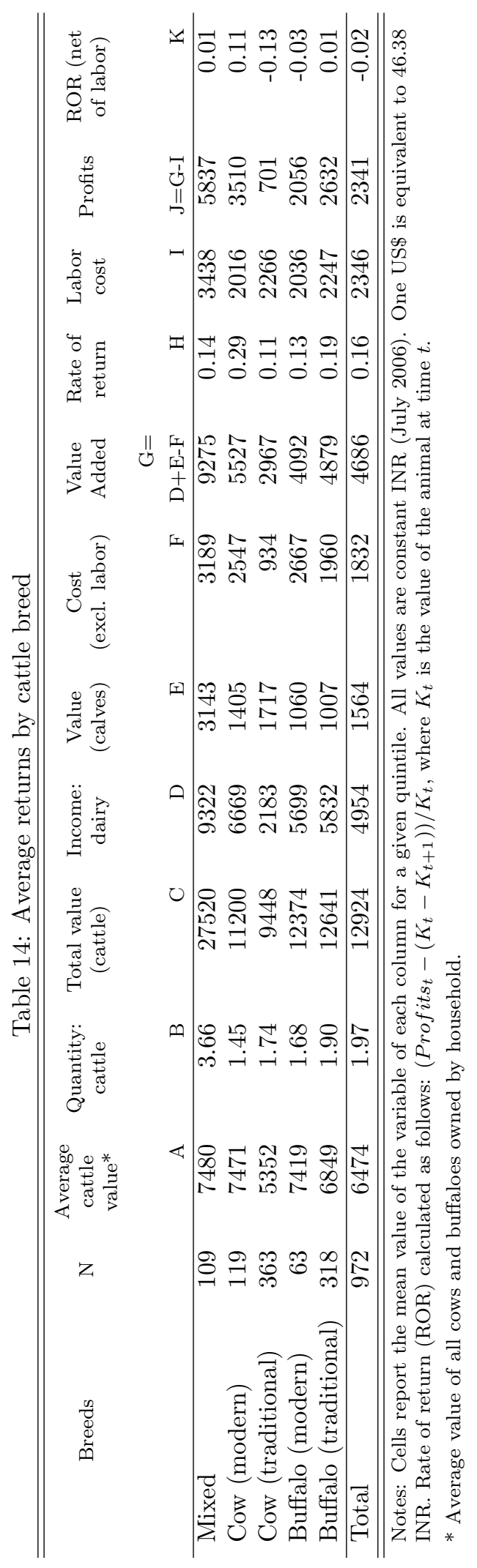


Table 15: Marginal returns to cattle by quintile of average cattle value

\begin{tabular}{lc}
\hline \hline & $(1)$ \\
\hline 1. Quintile & 0.050 \\
& $(0.119)$
\end{tabular}

2. Quintile 0.034

$$
(0.072)
$$

3. Quintile 0.003

$(0.050)$

4. Quintile 0.117

$(0.079)$

5. Quintile $0.141^{*}$

(0.058)

\begin{tabular}{lc}
\hline Observations & 972 \\
\hline \hline
\end{tabular}

Notes: Pooled OLS. Clustered std. errors in parentheses.

Controls are those of main model. Cells report average marginal effects of cattle value. ${ }^{*} p<0.05,{ }^{* *} p<0.01$, ${ }^{* * *} p<0.001$

Table 16: Marginal returns to cattle by cattle breed

\begin{tabular}{lc}
\hline \hline & $(1)$ \\
\hline Mixed & $0.082^{+}$ \\
& $(0.047)$ \\
Cow (modern) & $0.314^{* * *}$ \\
& $(0.081)$ \\
Cow (traditional) & 0.025 \\
& $(0.056)$ \\
Buffalo (modern) & -0.050 \\
& $(0.070)$ \\
Buffalo (traditional) & 0.059 \\
& $(0.045)$ \\
\hline Observations & 972 \\
\hline \hline
\end{tabular}

Notes: Pooled OLS. Clustered std. errors in parentheses.

Controls are those of main model. Cells report average marginal effects of cattle value. ${ }^{*} p<0.05,{ }^{* *} p<0.01$, *** $p<0.001$ 
Table 17: Marginal returns to cattle by rainfall conditions

\begin{tabular}{lcc}
\hline \hline & $(1)$ & $(2)$ \\
\hline Total value: cattle & $0.165^{*}$ \\
& $(0.070)$ \\
Total value: cattle \# Rainfall (deviation) & $0.245^{* *}$ \\
& $(0.088)$ \\
Rainfall (deviation) & -1296.094 \\
& $(1016.613)$
\end{tabular}

\begin{tabular}{|c|c|}
\hline Marginal returns to cattle & \\
\hline at Rainfall (dev., lag) $=-0.5$ & $\begin{array}{c}0.043 \\
(0.072)\end{array}$ \\
\hline at Rainfall (dev., lag) $=-0.4$ & $\begin{array}{c}0.067 \\
(0.070)\end{array}$ \\
\hline at Rainfall (dev., lag) $=-0.3$ & $\begin{array}{c}0.092 \\
(0.068)\end{array}$ \\
\hline at Rainfall (dev., lag) $=-0.2$ & $\begin{array}{c}0.116^{+} \\
(0.068)\end{array}$ \\
\hline at Rainfall (dev., lag) $=-0.1$ & $\begin{array}{c}0.141^{*} \\
(0.068)\end{array}$ \\
\hline at Rainfall (dev., lag) $=0$ & $\begin{array}{c}0.165^{*} \\
(0.070)\end{array}$ \\
\hline at Rainfall (dev., lag) $=0.1$ & $\begin{array}{c}0.190^{*} \\
(0.073)\end{array}$ \\
\hline at Rainfall (dev., lag) $=0.2$ & $\begin{array}{c}0.214^{* *} \\
(0.077)\end{array}$ \\
\hline at Rainfall (dev., lag) $=0.3$ & $\begin{array}{c}0.239^{* *} \\
(0.081)\end{array}$ \\
\hline at Rainfall (dev., lag) $=0.4$ & $\begin{array}{c}0.263^{* *} \\
(0.086)\end{array}$ \\
\hline at Rainfall (dev., lag) $=0.5$ & $\begin{array}{c}0.288^{* *} \\
(0.092)\end{array}$ \\
\hline Observations & \\
\hline
\end{tabular}

